Historic, archived document

Do not assume content reflects current scientific knowledge, policies, or practices. 



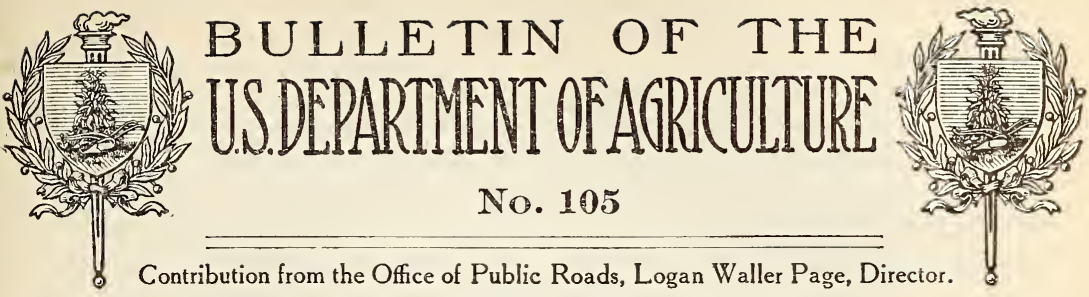

July 10, 1914.

(PROFESSIONAL PAPER.)

\title{
PROGRESS REPORTS OF EXPERIMENTS IN DUST PREVENTION AND ROAD PRESERVATION, 1913.
}

\author{
EXPERIMENTS AT CHEVY CHASE, MD. \\ (Completion of 1912 project.)
}

CEMENT CONCRETE, OIL-CEMENT CONCRETE, VITRIFIED BRICK, AND BITUMINOUS SURFACE TREATMENTS ON CONCRETE.

The 1912 experimental project is located upon a section of Kensington Road (Connecticut Avenue extended), extending north from Bradley Lane to the loop of the Capital Traction Co. tracks at Chevy Chase Lake. This total length of 6,195 feet was covered by six experimental sections, as follows:

Experiment No. 1, bituminous concrete (Topeka specification).

Experiment No.2, bituminous concrete (District of Columbia specification).

Experiment No. 3, crment and oil-cement concrete surface treated with bituminous materials.

Experiment No. 4, oil-cement concrete.

Experiment No. 5, cement concrete.

Experiment No. 6, vitrified brick.

The work was begun September 9, 1912, and was continued until December 13, 1912, when, owing to unfavorable weather conditions, it was discontinued, after 4,561 feet had been partially completed. A complete report of the work accomplished in 1912, with approximate cost data, was published in Office of Public Roads Circular No. 99. The following report covers the completion of the project with such repetition as may appear necessary to a better understanding of the methods pursued.

NotE.-This bulletin gives the details of construction of several sample roads constructed under the supervision of the Office of Public Roads. It is of interest to all sections where improvement of roads is contemplated or necessary.

$41701^{\circ}-14-1$ 
Experinent No. 3.-Cenent Concrete axd oil-cenent concrete (surfaces Location: TREATED WITH BITUMINOUS MATERIALS).

Cement concrete-

Station $12+50$ to station $15+84$, gravel aggregate.

Station $15+84$ to station $21+60$, limestone aggregate.

Station $21+60$ to station $25+03$, gravel aggregate.

Oil-cement concrete-

Station $25+03$ to station $2 \bar{\imath}+29$, limestone aggregate.

Total length:

Station $27+29$ to station $30+90$, limestone aggregate.

Cement concrete section-1,253 feet.

Oil-cement concrete section- $58 \mathrm{i}$ feet.

Total area:

Cement concrete section-2,837 square yards.

Oil-cement concrete section-1,341 square yards.

The details regarding the construction of both types of concrete are fully described in Circular No.99, and repeated in this report under experiments Nos. 4 and 5.

As noted in Circular No. 99, the concrete for these experiments was completed in the fall of 1912 , but owing to cold weather it was necessary to postpone the application of surface treatments until 1913. The surface of the concrete was then washed, thoroughly swept, and allowed to dry off, after which a number of bituminous materials, singly and in combination, was applied. Where a paint coat is indicated, it signifies a thin surface application of a material for the purpose of possibly securing better adhesion than might otherwise be obtained for the wearing or carpet coat. The paint coats were broomed over the surface without heating. The heavier products were heated in three-barrel kettles, and spread over the surface by means of a hand-drawn distributor of about 30 gallons capacity, so designed as to permit the material to flow out in a thin sheet about 18 inches wide.

The applications were then corered with pea gravel or limestone grits applied by a spreading machine and the road was immediately opened to traffic.

The locations selected for the various sections are indicated by lettered markers along the roadside. The following is a tabular description of these sections: 
TABLE 1.-Description of various sections of experiment No. 3.

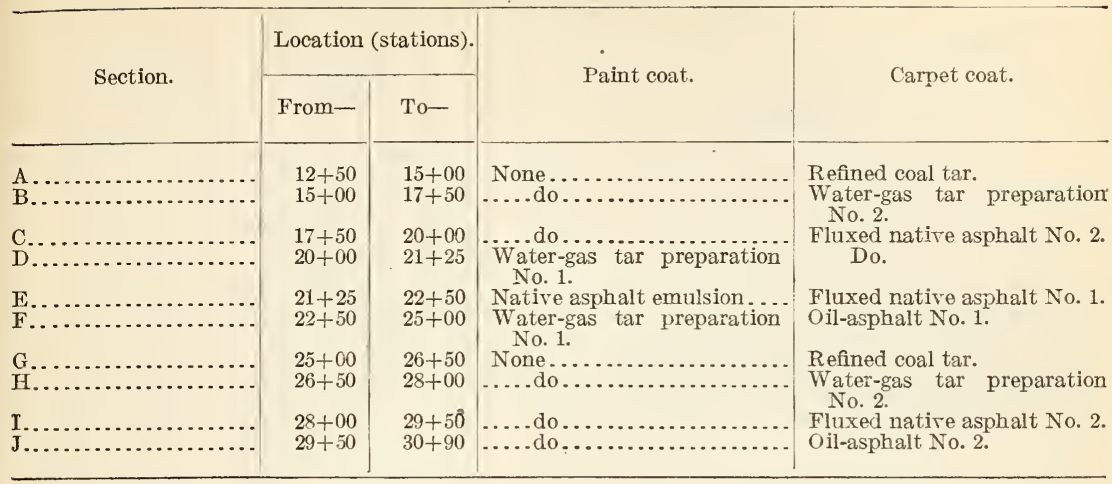

Analyses of the various materials used are given in Tables Nos. 2 and 3. A sample of the asphaltic emulsion was not obtained, but it was the same product as was used on section No. 11 of the 1911 project and reported in Circular No. 99. For a paint coat the emulsion was diluted with an equal volume of water.

From station $33+60$ to station $34+15$ the concrete was given a paint coat of the crude water-gas tar, the analysis of which is given in Table 2. The application was made at the rate of approximately 0.1 gallon per square yard. It was absorbed to a slight extent and soon dried, and was distinctly evident as a brown stain on the surface when last inspected.

TABLE 2.-Analyses of tar products used in surface treatment of concrete.

\begin{tabular}{|c|c|c|c|c|c|c|c|c|}
\hline \multirow{2}{*}{ Materials. } & \multirow{2}{*}{\multicolumn{2}{|c|}{$\begin{array}{l}\text { Crude water- } \\
\text { gas tar. }\end{array}$}} & \multirow{2}{*}{\multicolumn{2}{|c|}{ Refined coal tar. }} & \multicolumn{4}{|c|}{ Water-gas tar preparation. } \\
\hline & & & & & No & 1 & No. & 2. \\
\hline \multicolumn{3}{|c|}{ 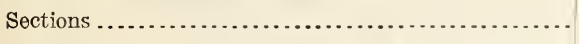 } & \multicolumn{2}{|c|}{$A$ and $\mathrm{G}$. } & \multicolumn{2}{|c|}{$\mathrm{D}$ and $\mathrm{F}$. } & \multicolumn{2}{|c|}{$\mathrm{B}$ and $\mathrm{H}$. } \\
\hline \multirow[t]{2}{*}{ 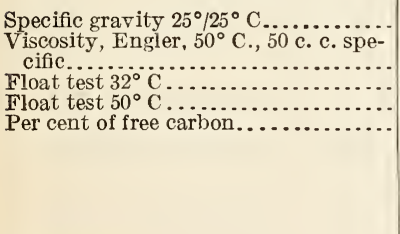 } & \multicolumn{2}{|c|}{1.082} & \multicolumn{2}{|c|}{1.219} & \multicolumn{2}{|c|}{$\begin{array}{l}1.108 \\
14.0 \\
0.25\end{array}$} & \multicolumn{2}{|c|}{$\begin{array}{c}1.144 \\
3,3, \cdots \\
3^{\prime} 27^{\prime \prime} \\
1^{\prime} 15^{\prime \prime} \\
0.95\end{array}$} \\
\hline & $\begin{array}{l}\text { By rol- } \\
\text { ume. }\end{array}$ & $\begin{array}{c}\text { By } \\
\text { weight. }\end{array}$ & $\begin{array}{l}\text { By vol- } \\
\text { ume. }\end{array}$ & $\begin{array}{c}\text { By } \\
\text { weight. }\end{array}$ & $\begin{array}{l}\text { By vol- } \\
\text { ume. }\end{array}$ & $\underset{\text { weight. }}{\text { By }}$ & $\begin{array}{c}\text { By rol- } \\
\text { ume. }\end{array}$ & $\begin{array}{c}\text { By } \\
\text { weight. }\end{array}$ \\
\hline \multirow[t]{2}{*}{ 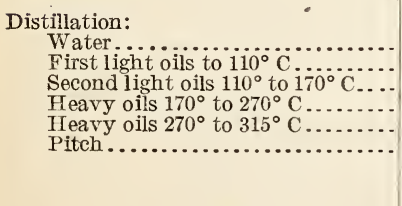 } & $\begin{array}{rr}P . c t . \\
1 & 7.5 \\
1 & 6.3 \\
1 & 1.1 \\
4 & 25.1 \\
6 & 16.4 \\
4 & 43.6\end{array}$ & $\begin{array}{r}P . c t . \\
6.9 \\
5.1 \\
.8 \\
23.4 \\
15.5 \\
47.8\end{array}$ & $\begin{array}{r}\text { P. ct. } \\
0.0 \\
2.8 \\
3.3 \\
516.4 \\
710.0 \\
72.5\end{array}$ & $\begin{array}{r}P . c t . \\
0.0 \\
.5 \\
.2 \\
14.7 \\
8.7 \\
75.8\end{array}$ & $\begin{array}{r}P . c t . \\
0.0 \\
11.7 \\
1.6 \\
118.5 \\
818.4 \\
60.8\end{array}$ & $\begin{array}{r}P . c t . \\
0.0 \\
1.4 \\
.4 \\
16.3 \\
17.0 \\
64.8\end{array}$ & $\begin{array}{r}\text { P. ct. } \\
0.0 \\
1.2 \\
1.2 \\
17.5 \\
911.8 \\
80.3\end{array}$ & $\begin{array}{r}\text { P. ct. } \\
0.0 \\
.1 \\
.2 \\
6.4 \\
10.4 \\
82.8\end{array}$ \\
\hline & 100.0 & 99.5 & 100.0 & 99.9 & 100.0 & 99.9 & 100.0 & 99.9 \\
\hline
\end{tabular}

${ }^{1}$ Clear. 2 One-half solid. ${ }^{3}$ Cloudy. 4 Three-fourths solid. 5 Two-thirds solid. 6 Two-fifths solid. ${ }^{7}$ Solid. 8 Clear. Showed 7.5 per cent insolubie in dimethyl sulphate. A $315^{\circ}-350^{\circ} \mathrm{C}$. fraction showed 7.5 per cent, and $a 50^{\circ}-375^{\circ} \mathrm{C}$. fraction showed 17.5 per cent insoluble in dimethyl sulphate.

${ }^{9} \mathrm{Clear}$. This fraction, and also a $315^{\circ}-350^{\circ} \mathrm{C}$. fraction and a $350^{\circ}-375^{\circ} \mathrm{C}$. fraction each showed 7.5 per cent insoluble in dimethyl sulphate. 
TABLE 3.-Analyses of native and oil-asphalt products used in the surface treatment of concrete.

\begin{tabular}{|c|c|c|c|c|}
\hline \multirow{2}{*}{ Materials. } & \multicolumn{2}{|c|}{$\begin{array}{l}\text { Fluxed native } \\
\text { asphalt. }\end{array}$} & \multicolumn{2}{|c|}{ Oil asphalt. } \\
\hline & No. 1. & No. 2. & No. 1. & No. 2 , \\
\hline Sections.. & E. & $\begin{array}{c}\mathrm{C}, \mathrm{D} \text {, and } \\
\mathrm{I} \text {. }\end{array}$ & F. & J. \\
\hline 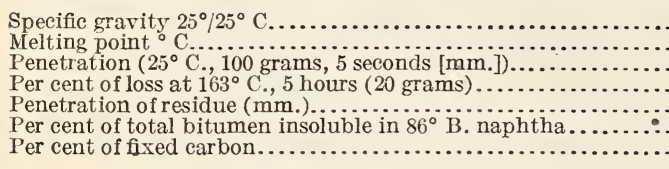 & $\begin{array}{l}1.045 \\
39 \\
18.4 \\
3.50 \\
6.3 \\
19.60 \\
9.83\end{array}$ & $\begin{array}{l}1.043 \\
48 \\
14.8 \\
2.73 \\
6.4 \\
21.87 \\
11.17\end{array}$ & $\begin{array}{l}1.031 \\
92 \\
12.6 \\
.32 \\
1.8 \\
34.84 \\
15.62\end{array}$ & $\begin{array}{l}1.012 \\
52 \\
14.7 \\
.59 \\
10.3 \\
21.72 \\
10.92\end{array}$ \\
\hline 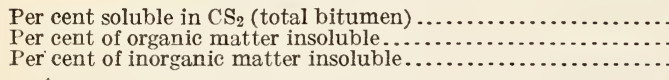 & $\begin{array}{r}94.70 \\
1.23 \\
4.07\end{array}$ & $\begin{array}{r}96.56 \\
1.35 \\
2.09\end{array}$ & $\begin{array}{r}99.74 \\
.17 \\
.09\end{array}$ & $\begin{array}{r}99.72 \\
.17 \\
.11\end{array}$ \\
\hline & 100.00 & 100.00 & 100.00 & 100.00 \\
\hline
\end{tabular}

1 Penetration $\left(0^{\circ} \mathrm{C}\right.$, 200 grams, 1 minute) $1.4 \mathrm{~mm}$; penetration $\left(46^{\circ} \mathrm{C} ., 50\right.$ grams, 5 seconds $) 5.8 \mathrm{~mm}$.

Location:

ExPERIMENT No. 4.-OIL-CEMENT CONCRETE.

Station $30+90$ to station $33+60$, gravel aggregate.

Station $42+50$ to station $44+61$, limestone aggregate.

Station $46+10$ to station $49+00$, trap rock aggregate.

Total length: 771 feet.

Total area: 1, 744 square yards.

Methods and materials.-Owing to irregularity in the delivery of the materials, it became necessary to build experiments Nos. 4 and 5 in separated sections. The first two sections in the order above given were completed in 1912, while the third was built in the spring of 1913 .

The concrete was mixed in a mechanical mixer of the self-propelled rotary-distributor type. The proportions were 1 part of Portland cement to $1 \frac{3}{4}$ parts of sand and 3 parts of coarse aggregate, with enough water to produce a concrete of quaky consistency. A light residual petroleum having the characteristics given below in Table No. 5 was mixed with the concrete to the amount of 5 pints per bag of cement. This mixture was accomplished by delaying the introduction of the oil until after the cement, sand, coarse aggregate, and water had been partially mixed. The concrete was spread evenly over the subgrade to a depth slightly greater than the finished thickness of 6 inches and the surface was then "struck off" by means of a well-designed "strike board." After this the surface was finished to true grade and cross-section with a wooden float. The floating was done from a bridge which rested upon the side forms and the conerete gutter. Expansion joints were purposely omitted and no joints of any other kind were constructed except those between the days' work, and these were formed at an angle of 80 degrees to the center line of the road. Before continuing the work of laying the 
concrete the faces of such joints were washed with a 10 per cent solution of muriatic acid and then with water.

Protection of concrete after laying.-As soon as practicable after laying the pavement it was covered with canvas and was so protected until the concrete had set hard enough for it not to be injured by a man walking upon it. The canvas was then removed and the concrete was covered with a layer of loam or sand about 2 inches in depth. This was kept wet for a period of 8 days. The covering was allowed to remain on the pavement for a period of 15 days, after which it was removed whenever it was convenient to do so.

Typical mechanical analyses of all the coarse aggregates used are given in Table 4.

TABLE 4.-Mechanical analyses of coarse aggregates used in all concrete experiments.

\begin{tabular}{|c|c|c|c|}
\hline & Gravel. & $\begin{array}{l}\text { Lime- } \\
\text { stone. }\end{array}$ & Trap. \\
\hline 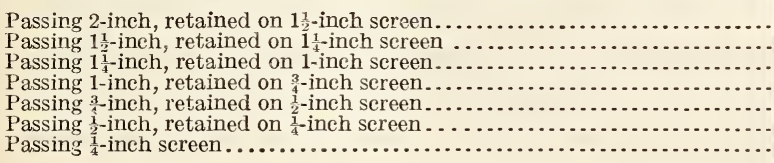 & \begin{tabular}{r|}
2.3 \\
10.8 \\
24.0 \\
25.8 \\
26.4 \\
9.8 \\
.9
\end{tabular} & $\begin{array}{r}13.2 \\
34.2 \\
47.4 \\
5.2\end{array}$ & $\left\{\begin{array}{r}6.6 \\
19.5 \\
40.6 \\
24.9 \\
8.4\end{array}\right.$ \\
\hline & 100.0 & 100.0 & 100.0 \\
\hline
\end{tabular}

TABLE 5.-Analyses of fluid residual petroleum used in oil-cement concrete for experimert No. 4 .

Specific gravity $25^{\circ} / 25^{\circ} \mathrm{C}$

Viscosity, Engler, $50^{\circ}$ C., 100 c. c. specific......................... 27.8

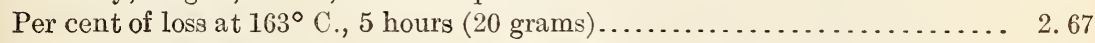

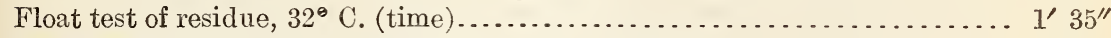

Per cent of total bitumen insoluble in $86^{\circ} \mathrm{B}$. naphtha.................. 2.31

Per cent of fixed carbon..................................... 3.01

Per cent soluble in $\mathrm{CS}_{2}$ (total bitumen) ........................ 99.90

Per cent of organic matter insoluble.......................... . 08

Per cent of inorganic matter insoluble.......................... . 02

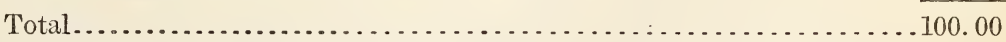

Hydrated lime experiment.-Between stations $47+90$ and $49+00$ hydrated lime was also added to the concrete. The proportioning of the mixture for this section of the experiment was as follows: Hydrated lime, 20 pounds; cement, 188 pounds; sand, 4 cubic feet; coarse aggregate, $7 \frac{1}{2}$ cubic feet; and oil, 10 pints.

Location:

Experiment No. 5.-Cenent concrete.

Station $33+60$ to station $37+85$, gravel aggregate.

$\left.\begin{array}{l}\text { Station } 37+85 \text { to station } 42+50 \\ \text { Station } 44+61 \text { to station } 46+10\end{array}\right\}$ limestone aggregate.

Station $46+10$ to station $52+00$, trap rock aggregate.

Total length: 1,339 feet.

Total area: 3,013 square yards. 
Methods and materials.-The same procedure was followed as in the construction of experiment No. 4, excepting for the omission of the oil from the mixture. From station $33+60$ to station $42+50$ this section was completed in 1912 , but the remainder of the construction was carried out in the spring of 1913.

Hydrated lime experiment.-Between station $49+00$ and station $50+50$, and joining the same experiment in the oil-cement concrete, hydrated lime was added to the concrete. The proportions were the same as given in experiment No. 4, except the omission of the oil.

Experiment No. 6.-Vitrified BRick.

Location: Station $52+00$ to station $61+80$.

Area: 2,055 square yards.

Concrete base and shoulder.-The concrete base was similar in character and construction to that used in experiments Nos. 1 and 2, and described in Circular No.99. The concrete was made up of 1 part by volume of Portland cement, 3 parts of sand, and 7 parts of gravel. A bag of cement was considered as having a volume of 1 cubic foot. The concrete was mixed in a mechanical concrete mixer of the selfpropelled, rotary-distributor type, the flow from which was practically continuous, and the distributor was swung across the road and the mixer moved ahead in such manner as to place the concrete upon the subgrade in approximately the position desired. It was then shoveled into place in such an amount as to form when compacted with concrete tampers a uniform layer 6 inches in thickness.

Before the concrete base had taken initial set, a concrete shoulder 8 inches wide and 6 inches high, mixed in the proportions of 1 part of cement, $1 \frac{3}{4}$ parts of sand, and 3 parts of gravel was placed upon all the edges of the base except those which abut against the concrete gutter.

Sand cushion.-The cushion sand was spread orer the base to an approximate depth of 2 inches and struck off to a true depth of 2 inches by the use of a "strike board," the ends of which rested upon the concrete curbs. The cushion was then rolled with a lawn roller weighing 300 pounds. After the first rolling, sand was spread over the rolled surface to a depth of about one-fourth inch, and again struck off and thoroughly rolled. A mechanical analysis of the sand used is given in Table 6.

TABLE 6.- Mechanical analysis of the cushion sand.

Per cent.

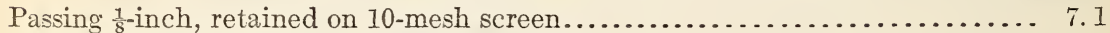

Passing 10-mesh, retained on 20 -mesh screen ....................... 13.7

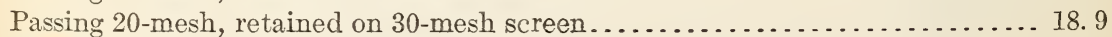

Passing 30 -mesh, retained on 40 -mesh screen ......................... 20.5

Passing 40 -mesh, retained on 50 -mesh screen...................... 16.8

Passing 50 -mesh, retained on 80 -mesh screen ......................... 13.7

Passing 80 -mesh, retained on 100 -mesh screen......................... 1.4

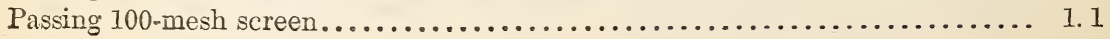


The brick.-Fourteen varieties of paving block were laid, and Table 7 shows their different descriptions and locations.

TABLE 7.-Brick used in experiment No. 6.

\begin{tabular}{|c|c|c|c|}
\hline \multirow{2}{*}{ Section. } & \multicolumn{2}{|c|}{ Location (stations). } & \multirow{2}{*}{ Description. } \\
\hline & From- & To- & \\
\hline 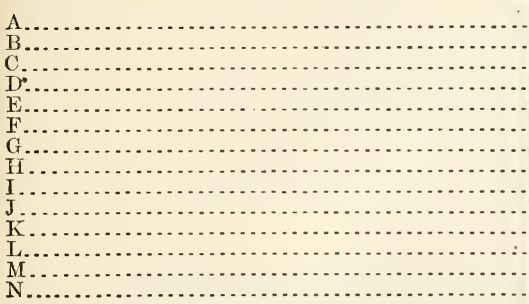 & $\begin{array}{l}52+00 \\
52+51.5 \\
53+19.0 \\
54+27.7 \\
55+32.7 \\
56+44.1 \\
57+13.5 \\
57+74.0 \\
58+41.9 \\
58+91.9 \\
59+53.2 \\
60+7.9 \\
60+66.7 \\
61+26.8\end{array}$ & $\begin{array}{l}52+51.5 \\
53+19.0 \\
54+27.7 \\
55+32.7 \\
56+41.1 \\
57+13.5 \\
57+74.0 \\
58+41.9 \\
58+91.9 \\
59+53.2 \\
60+7.9 \\
60+66.7 \\
61+26.8 \\
61+78.1\end{array}$ & $\begin{array}{l}\text { Shale (wire-cut lug). } \\
\text { Do. } \\
\text { Shale, repressed. } \\
\text { Do. } \\
\text { Do. } \\
\text { Do. } \\
\text { Do. } \\
\text { Do. } \\
\text { Do. } \\
\text { Fire clay, repressed. } \\
\text { Do. } \\
\text { Shale, repressed. } \\
\text { Fire clay, repressed. } \\
\text { Fire clay (wire-cut luy). }\end{array}$ \\
\hline
\end{tabular}

The report of tests on samples of these brick is given in Table 8 .

TABLE 8.-Rattler, sand-blast, and absorption tests on vitrified brick used at Chevy Chase, Md.

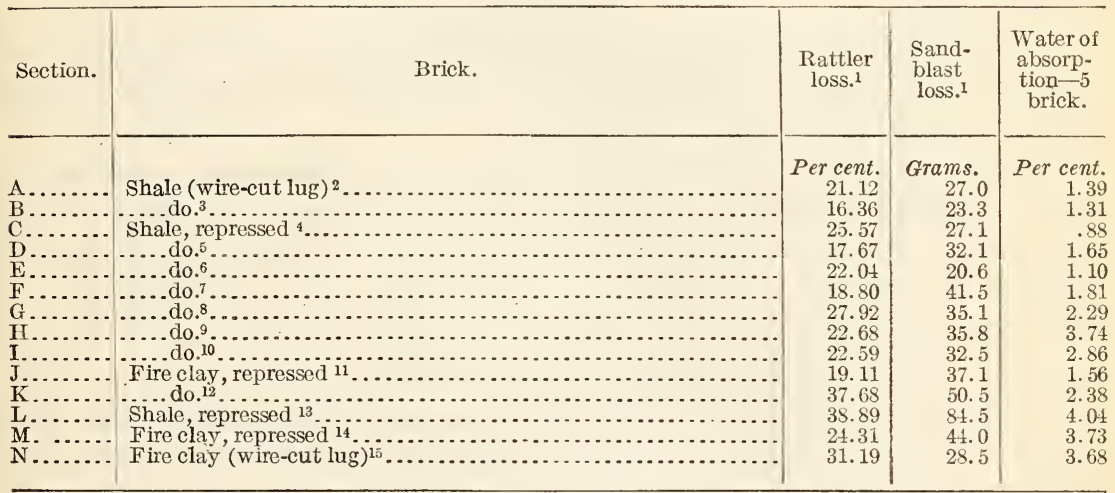

1 Average of three tests.

2 Hard-burned brick having a good structure.

3 Medium hard-burned brick having a very good structure.

4 Brick well vitrified; losses in rattler mainly due to chipping.

5 Brick molded from coarsely ground shale; had a fairly good structure and was hard burned.

6 Brick very hard burned; losses in rattler due to chipping.

7 Brick molded from coarsely ground clay; had a good structure.

8 Medium hard-burned brick which wear evenly, though excessively, in the rattler test.

9 Medium hard-burned brick made from finely ground clay and having a fairly good structure.

10 Medium hard brick made from coarsely ground clay and wearing down uniformly in rattler.

11 Brick made from coarsely ground fire clay; had an excellent structure, free from laminations; not burned very hard.

12 Comparatively soft-burned brick made from coarsely ground fire clay; wear in rattler excessive though uniform.

${ }_{13}$ Comparatively soft-burned brick made from coarsely ground clay; wear in rattler excessive though uniform.

${ }^{14}$ Fairly soft-burned brick made from medium finely ground clay; worn down evenly by rattler.

15 Losses in rattler due mainly to open laminations; brick hard burned.

Laying and grouting brick.-The brick were laid in straight courses at right angles to the curb. No driving was permitted to straighten the courses. After the brick were laid and all the spalls and imperfect bricks removed, the brick were rolled with a 5 -ton tandem roller 
until they were firmly bedded in the sand cushion. The joints were then filled with a cement grout composed of one part of Portland cement and one part of sand. Table 9 contains the mechanical analysis of the sand used.

TABLE 9.-Mechanical analysis of sand for grout.

Per cent.

Passing $\frac{1}{8}$-inch, retained on 10 -mesh screen. . . . . . . . . . . .

Passing 10 -mesh, retained on 20 -mesh screen...................... 1.5

Passing 20 -mesh, retained on 30 -mesh screen........................ 2.8

Passing 30 -mesh, retained on 40 -mesh screen.......................... 6.0

Passing 40-mesh, retained on 50 -mesh screen ....................... 30.6

Passing 50-mesh, retained on 80 -mesh screen........................ 41.1

Passing 80 -mesh, retained on 100 -mesh screen. . . . . . . . . . . . . . . . . 4.1

Passing 100-mesh, retained on 200 -mesh screen..................... 11.2

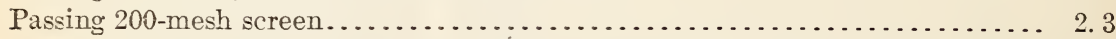

The grout was applied in two courses, the first of which was thin enough to run freely. This was swept into the joints by means of rattan hand brooms. After the first course had settled well into the joints and before any of it had dried, grout of the consistency of thick cream was squeegeed orer the parement, leaving all the joints completely filled.

Protection of the parement.-Immediately after the completion of the grouting, sand was spread orer the parement to a depth of onehalf inch and kept wet for seven days.

Expansion joints.-No transverse expansion joints were constructed and the ends of the parement are practically fixed. A longitudinal expansion joint was constructed along each curb line. From station $52+00$ to station $54+00$ it is 1 inch wide and was filled with a mixture of equal parts, by volume, of coal-tar pitch and Portland cement. From station $54+00$ to station $56+00$ the expansion joint is one-half inch wide and is filled with asphaltic felt, while from station $56+00$ to station $61+00$ the expansion joint is 1 inch wide and is filled with an oil asphalt having a penetration at $25^{\circ} \mathrm{C}$. of $3 \mathrm{~mm}$. and a melting point of $94^{\circ} \mathrm{C}$.

Measured bricks. - The thickness of a sufficient number of bricks of each variety to lay two courses across the pavement was measured. These bricks were then laid in the same manner as the other brick, and their location was carefully recorded, so that at any future time they may be taken from the parement, measured, and the amount of wear determined.

Cost data.-The cost data given in Circular No. 99 were necessarily subject to revision when the project was completed. Table 10 shows the cost of the entire work by experiments, together with a statement of the unit costs of material and labor prerailing on the work. 
Labor (per day of 8 hours):

TABLE 10.-Unit costs.

Superintendent.

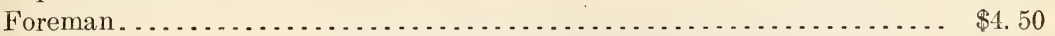

Rollerman......................................... $\$ 3.50$

Engineer for mixer..................................... $\$ 4.00$

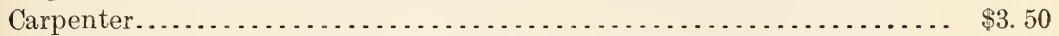

Laborer................................................... $\$ 1.60$

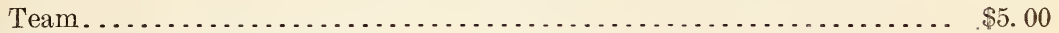

Materials f. o. b. nearest siding:

Sand.................................................

Gravel (for use in concrete gutter and base)......................

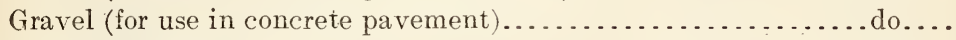

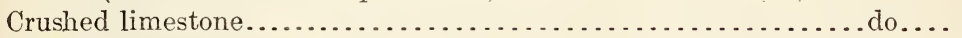

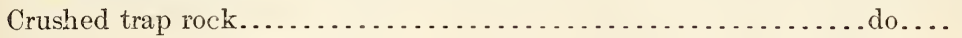

Cement..................................... . per barrel. .

Oil asphalts (cents) ....................... 10.13

Fluxed native asphalts (cents) ............................. 14. 10

Refined coal tar (cents)................................. 10.92

Water-gas tar preparation No. 2 (cents)....................... 8.42

Water-gas tar preparation No. 1 (cents)...................... $\quad 7.22$

Native asphalt emulsion (cents)............................ 13.00

Residual petroleum (cents)............................... 10. 70

4-inch vitrified clay tile (delivered on work) (cents)........ . per foot.. 6.69

Contract price for unloading and hauling materials from siding to w ork (average haul 3,100 feet):

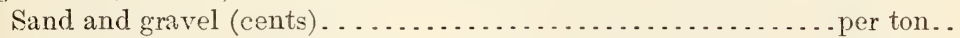

Crushed stone (cents) . . . . . . . . . . . . . . . . . . . . . . do...

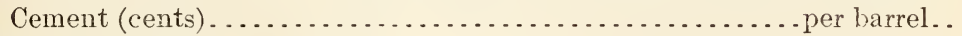

Machinery (per day):

Concrete mixer....................................... $\$ 10.00$

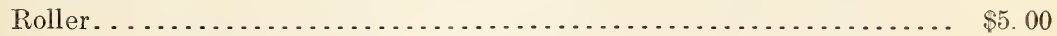

TABLE 11.-Concrete gutter.

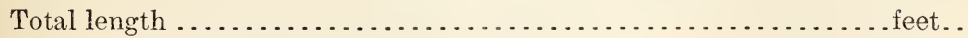

Quantities of materials per linear foot of gutter:

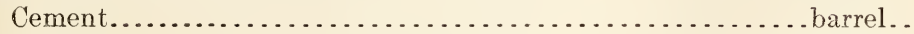

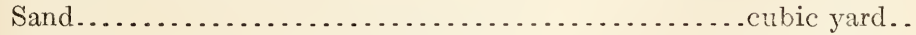

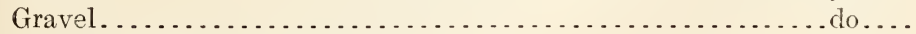

Cost data (cents per linear foot):

Cement.

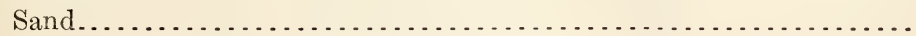

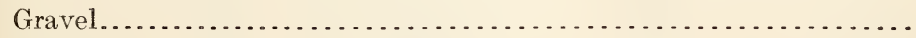

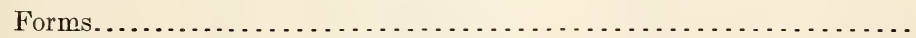

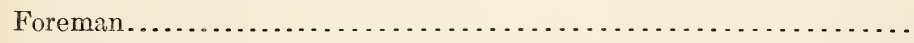

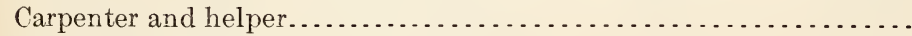

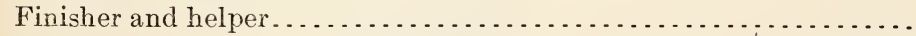

Labor

Total.

Total cost of gutter. 
TABLE 12.-Cost of miscellaneous work.

Building catch basin................................... $\$ 19.02$

Removing 10 trees............................................. 95.87

Removing old cobble gutter, 3,310 linear feet.......................... $\quad 79.61$

Labor on broken stone shoulder (from station $58+50$ to station $62+00$ ).... ${ }^{1} 62.50$

257.00

FRENCH DRAIN.

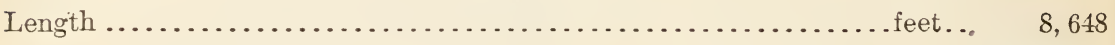

Labor:

Foreman...................................... $\$ 140.87$

Men.......................................... 846.87

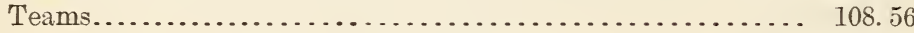

Materials:

Tile, 8,648 feet, at 6.7 cents per foot............... 579.42

Stone for filling trench ${ }^{2} \ldots \ldots \ldots \ldots \ldots \ldots \ldots \ldots \ldots \ldots \ldots \ldots \ldots . .52$

$\$ 1,096.30$

Cost per linear foot (cents)

1 Stone secured from excaration.

$2 \mathrm{~A}$ considerable quantity of stone for filling the trench was secured from the old macadam road. The labor necessary to secure this stone was so much that the drain would have cost but little more had fresh stone been purchased. 
DUST PREVENTION AND ROAD PRESFRVATION.

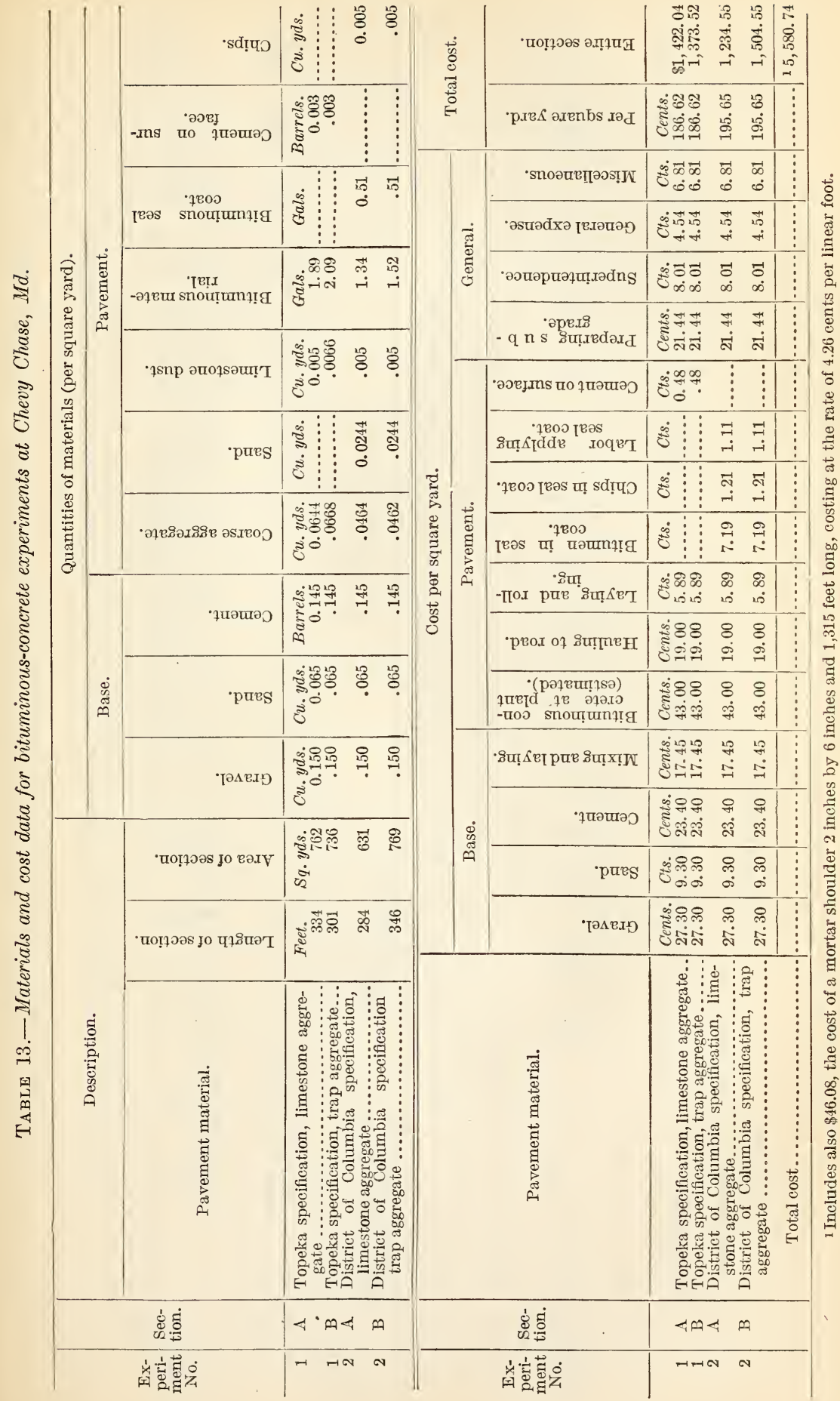


BULLETIN 105, U. S. DEPARTMENT OF AGRICULTURE.

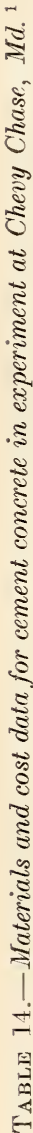

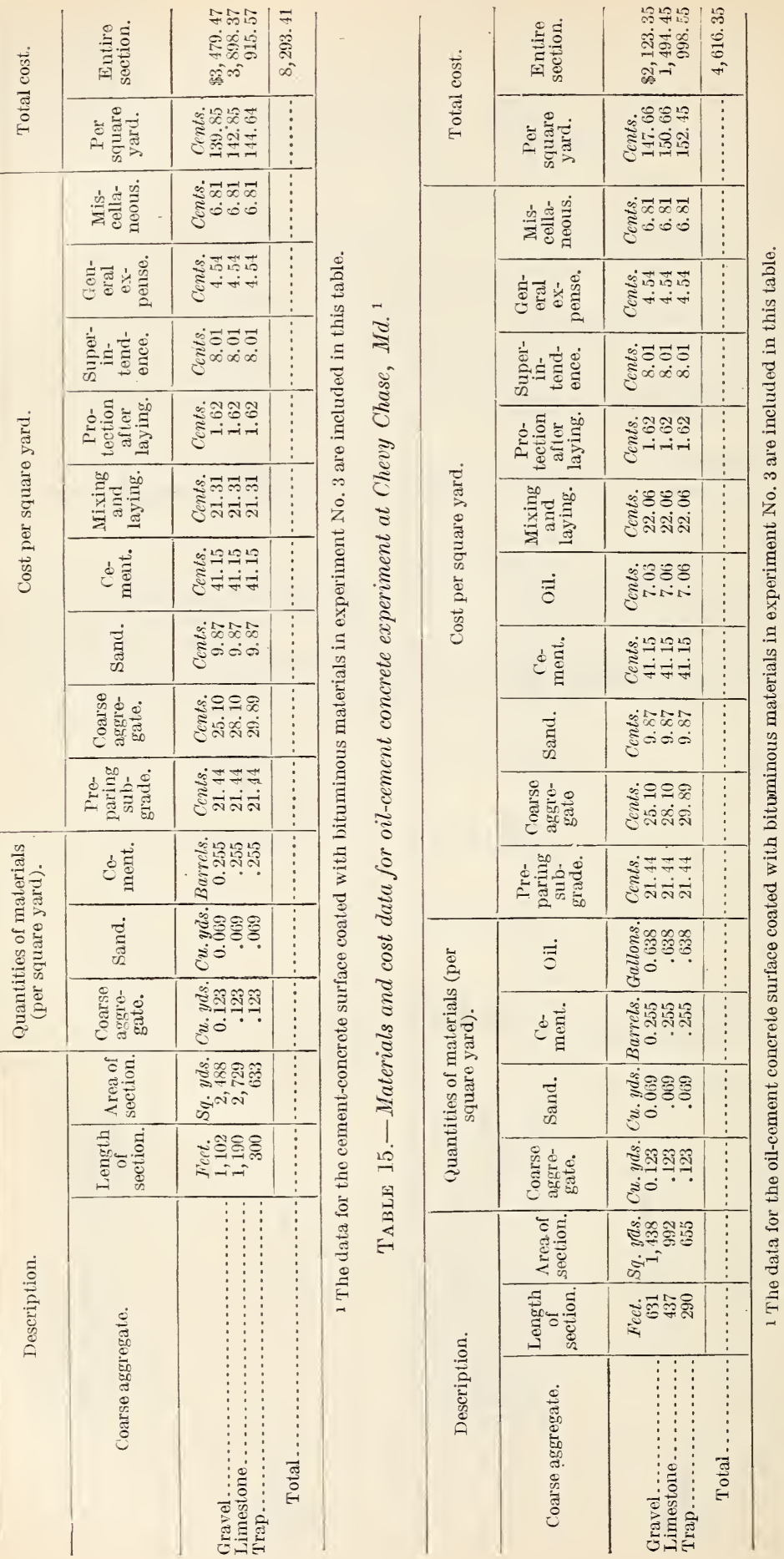




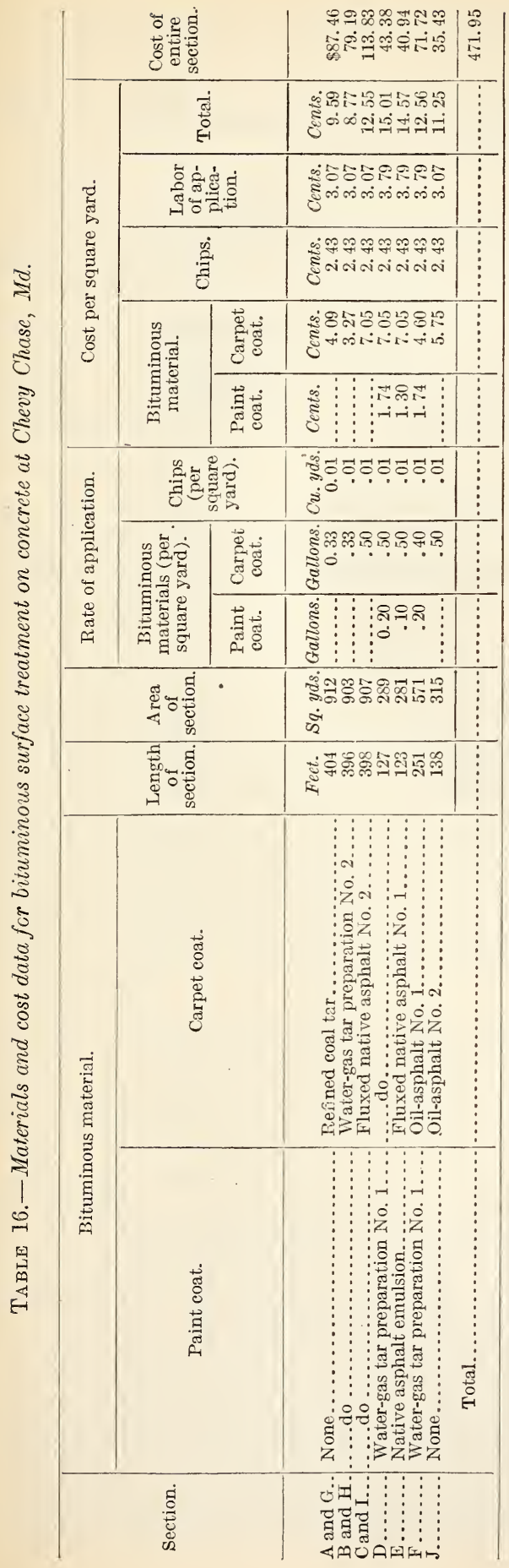


TABLE 17.-Materials and cost data for brick pavement at Chery Chase, Md.

Description:

Length of section $\ldots \ldots \ldots \ldots \ldots \ldots \ldots \ldots \ldots \ldots \ldots$. . . . . . . . .

Area of section. .......................... 2,055

Quantities of materials (per square yard):

Base-

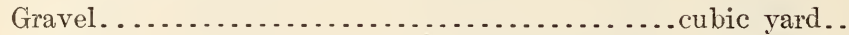

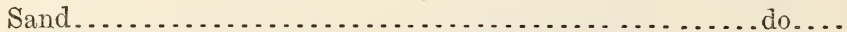

Cement.

barrel. .

0.145

Pavement-

Sand cushion. ..................................

Brick. . . . . . . .

Sand in grout.....................................

Cement in grout. . . . . . . . . . . . . . . . . . . . barrel.

0.031

Cost per square yard:

Base-

Gravel.............................................

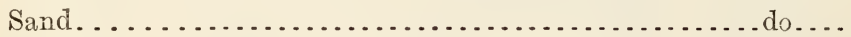

Cement. . . . . . . . . . . . . . . . . . . . . . . . . . . . do...

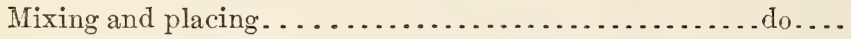

Pavement-

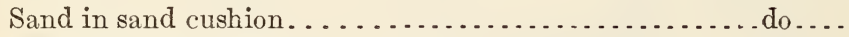

10. 10

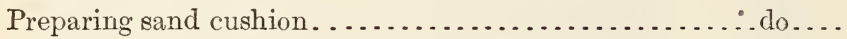

Brick... . . . . . . . . . . . . . . . . . . . . . . . . . . . do...

Unloading and piling brick from car . . . . . . . . . . . do...

Hauling and piling brick by roadside................. do ...

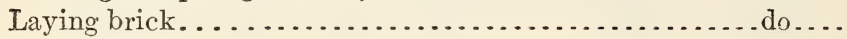

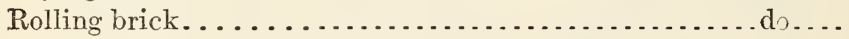

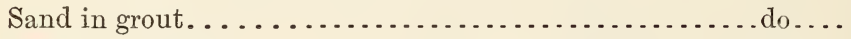

Cement in grout. . . . . . . . . . . . . . . . . . . . . . . . do...

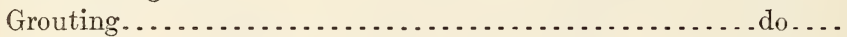

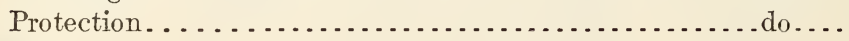

Preparing subgrade. ................................ do

Superintendence. . . . . . . . . . . . . . . . . . . . . . do...

General expense................................... do...

Miscellaneous........................................

Total cost:

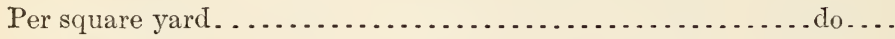

COMPLETE SUMMARY OF 1912 PROJECT AT CHEVY CHASE, MD.

On January 29, 1914, a careful inspection of all the experiments was made, and their condition was reported as follows:

Experiments Nos. 1 and 2, the bituminous concretes, are both in excellent condition. The section laid under the Topeka specification has a slightly wavy surface as compared with the District of Columbia pavement, and has compressed in a few places below the top of the

\footnotetext{
1 Includes also $\$ 136.59$, the cost of a concrete shoulder, 6 inches by 8 inches, $1,3 \tilde{0} 0$ linear feet at 10.12 cents per linear foot; and $\$ 73.05$, the cost of an expansion joint, 1,900 linear feet, at 3.84 cents per linear foot.
} 
adjoining curb. The seal coat on the District of Columbia pavement began to bleed badly with the advent of warm weather, and in July. it was necessary to make an application of pea gravel to the extent of 0.011 cubic yard per square yard. This is regarded as supplementary construction and charged accordingly. A smooth and excellent wearing surface has resulted.

The results of expansion in concrete during hot weather were noted at the joint between experiments Nos. 2 and 3, where the roadway buckled across its entire width, and to a small extent sheared off some of the concrete base of the District of Columbia parement. The defect was repaired by cutting out a narrow strip of concrete. The pavement settled to its original grade, and the slot was filled by three double courses of vitrified brick, the joints of which were filled with hot coal-tar pitch.

An inspection of the several bituminous surface treatments applied to concrete did not seem to indicate any noticeable difference between the adaptability of cement concrete and oil-cement concrete to this form of treatment. The condition of the various scctions at the time of inspection was noted as follows:

A (Refined coal tar): The adhesion was fairly good, but the bitumen had become quite hard and had worn off in a number of small spots.

B (Water-gas tar preparation No. 2): The adhesion was about the same as the coal tar, but much fewer places had worn through.

C (Fluxed native asphalt No. 2): The adhesion was not particularly good. There were no failures in the east half of the road, but for one-third of the width on the west side the treatment was about 30 per cent gone.

D (Fluxed native asphalt No. 2 over water-gas tar preparation No. 1): There were but few failures on the north two-thirds of the section; the bitumen was flexible and the adhesion good. There was extensive patching in the south third, but a large part of this was due to damage done by a traction engine shortly after the section was completed.

$\mathbf{E}$ (Fluxed native asphalt No. 1 over a native asphalt emulsion): The adhesion was poor. There were few small failures on the east half of the roadway, and about 40 per cent of the treatment was gone on the west half.

F (Oil asphalt No. 1 over water-gas tar preparation No. 1): The adhesion was poor, and the treatment was about 50 per cent gone throughout. One very good piece was left on the east half at the south end.

G (Refined coal tar): The condition was about the same as section A.

$H$ (Water-gas tar preparation No. 2): This section was in very good condition. The adhesion was good and there were only two or three very small bare places.

I (Fluxed native asphalt No. 2): The north half was good, but there were a few large bare places in the south half on the east side of the road.

$J$ (Oil asphalt No. 2): This section was generally good on the east half of the road, with several fairly large bare places along the west side.

In connection with the above report, it should be said that practically all of the sections suffered to a greater or less extent from the passage of a traction engine over them. This occurred during a rather warm spell shortly after the completion of the work, when the 
bitumen showed a slight tendency to blecd. The necessary repairs were rapidly made by the patrolman, but as scction markers had not then been placed, his costs could not be distributed. When the sections had once been put in thorough repair they were permitted to wear without further attention, with the results above given.

The expcsed concrete surfaces as a whole presented a smooth, uniform texture, and there was apparently no difference in wear between the plain cement and oil-cement concrete. The addition of hydrated lime has had no noticeable effect on the concrete. This section can not be distinguished from the others and has developed four cracks in a total length of 260 feet. Transverse cracks developed at varying intervals throughout the sections, and the average distance between cracks is shown in Table 18, which is based on observations made November 5, 1913. It should be noted that the cracks in the sections which had been surface-treated with bituminous materials include those which were noted before the surface treatment was applied as well as those which have since been noted through cracking of the bituminous surface.

TABLE 18.-Average distance between cracks in concrete road of Chevy Chase, Md.

\begin{tabular}{|c|c|c|c|}
\hline \multicolumn{2}{|l|}{ Character of pavement. } & \multirow{2}{*}{ Length. } & \multirow{2}{*}{$\begin{array}{c}\text { Average } \\
\text { distance } \\
\text { between } \\
\text { cracks. }\end{array}$} \\
\hline Concrete. & Aggregate. & & \\
\hline 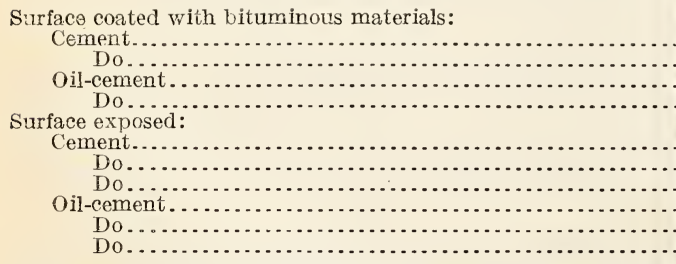 & 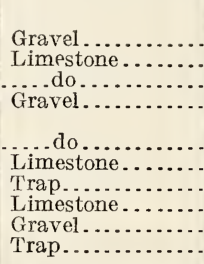 & $\begin{array}{l}\text { Feet. } \\
660 \\
583 \\
230 \\
370 \\
\\
425 \\
600 \\
300 \\
210 \\
263 \\
290\end{array}$ & $\begin{array}{r}\text { Fcet. } \\
45 \\
145 \\
115 \\
50 \\
61 \\
100 \\
40 \\
105 \\
45 \\
60\end{array}$ \\
\hline
\end{tabular}

It will be noted from the foregoing table that cracks have developed at a greater average distance where a limestone aggregate was used, and at the last inspection there were still two sections of the limestone concrete each 140 feet in length without a crack. When the edges of any cracks began to wear excessively, the cracks were filled with the water-gas tar preparation No. 1 and sand. The results of this treatment have thus far proved entirely satisfactory.

The measurements referred to in Circular No. 99 are being continued, and it is probable that interesting results will be reported in the near future.

No difference was noted in the character of the various sections of brick pavement. The grouted surface had practically all worn off, and it was observed at a few places throughout the length of the sec- 
tion that small transverse cracks had developed where the grout had broken loose from a course of brick.

Beginning with March 4, 1912, regular counts of traffic on the Connecticut Avenue sections were made. The census is taken every 13 days for a 24-hour period. A tabulation of the maximum and average of each class of traffic for the second one-year period, or 28 counts, for the period March 10, 1913, to February 24, 1914, is given in Table 19. The east side of the road carries outgoing traffic and the west side incoming traffic.

TABLE 19.- Volume and character of traffic on Connecticut Avenue north and south of Bradley Lane and west on Bradley Lane.

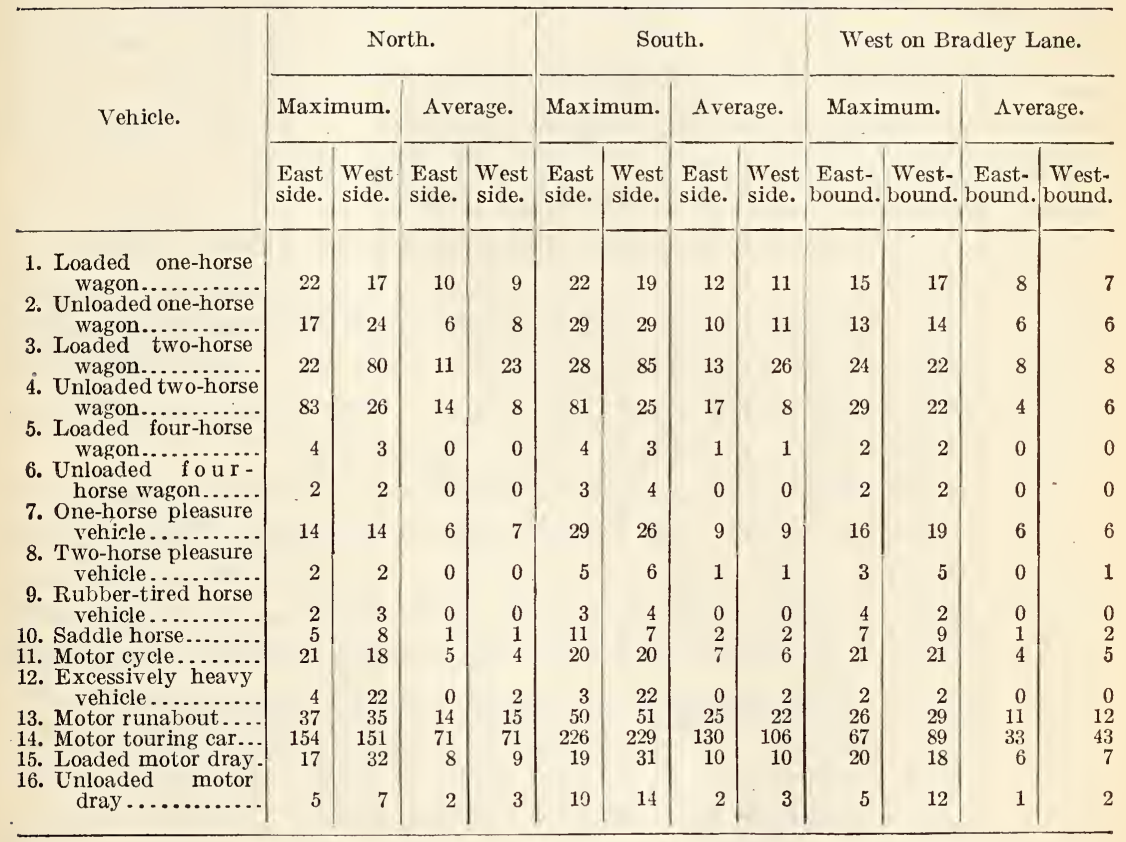

\section{EXPERIMENTS ON ROCKVILLE PIKE, MARYLAND.}

TARS AND OILS-SURFACE TREATMENT.

The principal purpose of these experiments was to demonstrate the relative value of several bituminous products commonly used for surface treatment, and to ascertain, by comparative service tests, the relative economy from a maintenance standpoint of cold treatment with the lighter products as compared with hot treatment in which some of the heavier products were used. Incidentally, the relative wearing qualities of trap-rock screenings and fine gravel will be practically tested, and on some of the sections where oil was applied, an attempt was made to learn what difference, if any, would result from making the application to a wet and dry road surface. 
The road selected for the experiments is commonly known as the Rockville Pike and extends from the District of Columbia line to the corporate limits of Rockville, Md., a distance of approximately 9 miles. It was a macadam road originally constructed with quartzite and patched with limestone from time to time. At the time of these experiments it had become rough and badly worn, and was therefore resurfaced before any surface treatments were applied. This work was done on three contracts, the first two of which, including the portion from station $0+15$ at the District line to station 210 , were completed in July, 1913, and the third, extending from station 210 to the corporate limits of Rockville, in October, 1913. The old surface was loosened with spikes in the roller wheels and further broken up with a 3 -ton scarifier. The surface was then reshaped and rolled, after which from 3 to $3 \frac{1}{2}$ inches of new limestone was added and the surface was finished as water-bound macadam. The road was graded 25 feet wide in both cuts and fills, and the surface of the finished macadam had a width of 15 feet and a crown of 0.6 inch per foot. The cost of this work averaged 52 cents per square yard or $\$ 4,676$ per mile of 15-foot road. A section of 10-foot road on Bradley Lane, 1,500 feet in length, was also scarified and resurfaced with limestone as waterbound macadam on a separate contract. This was a limestone road which had become badly worn and rutted. The total cost for resurfacing was $\$ 1,285.72$, or 75.6 cents per square yard.

Surface treatment was started on September 5 at the District line on the macadam which had been longest completed. The surface was thoroughly swept with a horse-drawn street sweeper, and any hard cakes of dust were removed with shovels. As the work progressed over macadam which had been more recently completed, these cakes of dust became more numerous, and were removed with considerable difficulty. The advisability of permitting traffic to consolidate and wear a new macadam surface to a reasonable extent before surface treating was thereby demonstrated. All the bituminous materials were delivered in tank-car lots of from 5,600 to 5,800 gallons with an average haul of $1 \frac{1}{8}$ miles from the road. The material was heated at first by a small portable boiler, but as colder weather developed it was found necessary to engage a 40-horsepower traction engine in order to heat the heavier materials properly.

The application was made by means of two 600-gallon distributors which were each drawn by one team. They were equipped with a gasoline pump developing about 40 pounds pressure at the nozzles. The material was ejected from slotted nozzles in fan-shaped sprays so spaced as to cover half the width of the road on each passage of the machine. 
The specification required that the bituminous material should be allowed to lie on the road surface for from one to three hours before being covered. It was soon noted, however, that on warm days a part of the material was lost by drainage over the shoulders and the practice of immediately covering the application with screenings or gravel was therefore adopted. Approximately the south half of each experiment was covered with trap rock screenings, while the north half was covered with fine river gravel. The latter material, used in the first three experiments, tended to run somewhat coarser than that obtained later, but no appreciable difference in results was noted after the road had been subjected to traffic for a short time.

The mechanical analyses of the average run of trap rock and gravel are given in Table 20.

TABLE 20.-Mechanical analyses of covering materials used in Rockville Pike experiments.

\begin{tabular}{|c|c|c|}
\hline Máterial. & $\begin{array}{l}\text { Trap } \\
\text { rock. }\end{array}$ & Gravel. \\
\hline 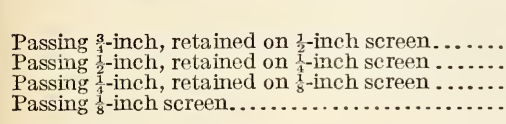 & $\begin{array}{r}\text { Pcr cent. } \\
30.5 \\
65.3 \\
3.7 \\
.5\end{array}$ & $\begin{array}{r}\text { Per cent. } \\
5.2 \\
62.0 \\
29.0 \\
3.8\end{array}$ \\
\hline Total.. & 100.0 & 100.0 \\
\hline
\end{tabular}

Experiment No. 1.-Refined coal tar-Hot application.

Location: Station $0+15$ to station $61+20$.

Length: 6,105 feet.

Bradley Lane was also treated for a width of 10 feet and a length of 665 feet east from Rockville Pike.

Date of application: From September 9 to September 22.

Temperature of tar: From $165^{\circ}$ to $200^{\circ} \mathrm{F}$.

TABLE 21.-Analysis of refined coal tar used in experiment No. 1.

Specific gravity $25^{\circ} / 25^{\circ} \mathrm{C}$

1.204

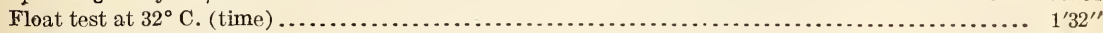

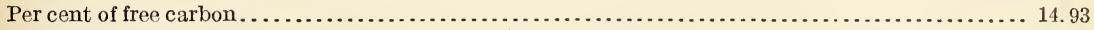

Distillation:

By volume. By weight.

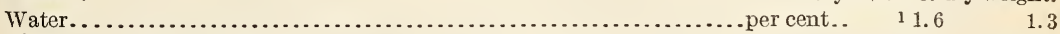

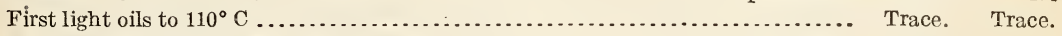

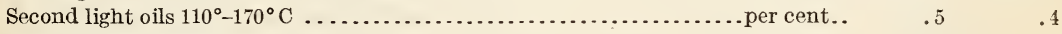

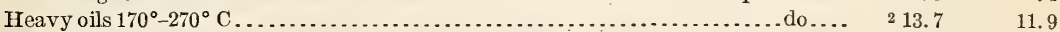

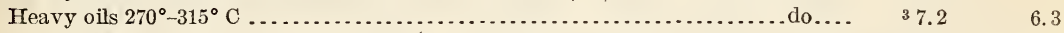

Pitch residue ................................................. ${ }^{4} 77.0 \quad 79.8$

Total ........................................................

From leaky coils in tank car. ${ }^{2}$ Four-fifths solid. ${ }^{3}$ One-fourth solid. ${ }^{4}$ Fairly glossy; brittle. 
Expertuent No. 2.-Reflned Water-gas tar-Cold application.

Location: From station $61+20$ to station $135+00$.

Length: 7,380 feet.

Bradley Lane was also treated for a width of 10 feet and a length of 835 feet east from the end of the preceding experiment.

Date of application: September 23 and 24.

Temperature of tar: From $80^{\circ}$ to $100^{\circ} \mathrm{F}$.

TABLE 22.-Analysis of refined water-gas tar used in experiment No. 2.

Specific gravity $25^{\circ} / 25^{\circ} \mathrm{C}$

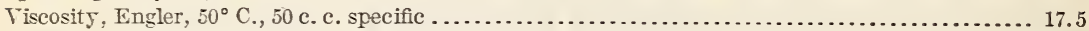

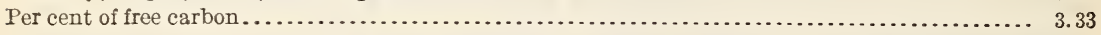

Distillation: By rolume. By weight.

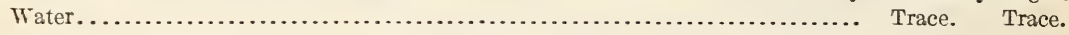

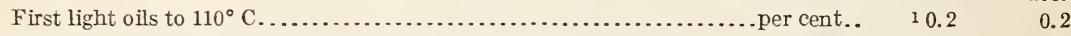

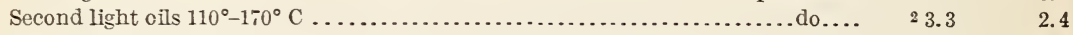

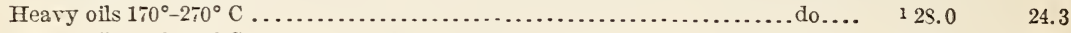

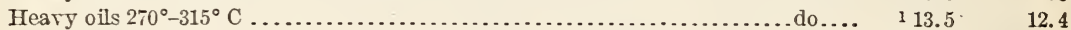

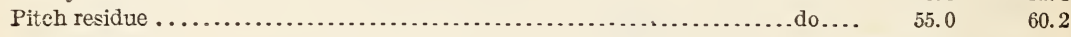

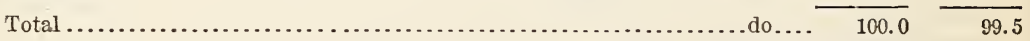

Experiment No. 3.-Asphaltic petroleum-Cold application.

Location: From station. $135+00$ to station $209+00$.

Length: 7,400 feet.

Date of application: From September 25 to September 30.

Temperature of oil: About $80^{\circ} \mathrm{F}$.

TABLE 23.-Analysis of asphaltic petroleum ${ }^{3}$ used in experiment No. 3.

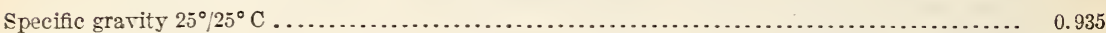

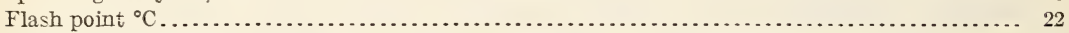

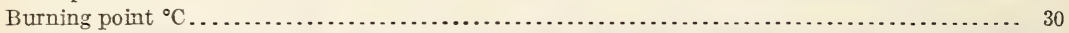

Viscosity, Engler, $25^{\circ}$ C., 50 c. c. specific .................................................... 67.0

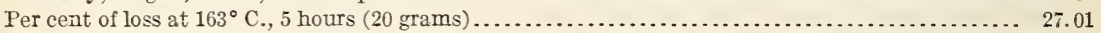

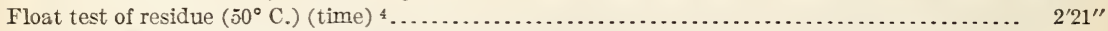

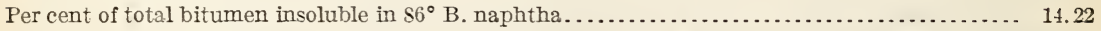

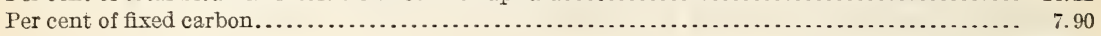

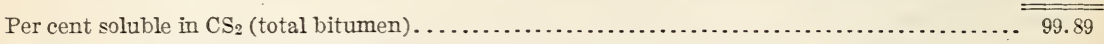

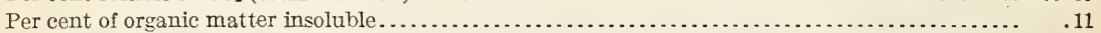

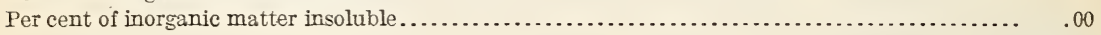

Total.................................................................

Details.-The oil was distributed in one application from station $135+00$ to station $175+00$, but on the remainder of this section about 0.25 gallon was applied on one day and another 0.25 gallon was applied the next day, after which the screenings or grarel were thrown on and the surface was rolled. From station $196+00$ to station $206+00$ the macadam was first well sprinkled with water and the oil was applied while the road surface was still moist.

1 Clear. 2 Turbid. $\quad{ }^{3}$ Fairly viscous, slightly sticky, fluid. $\quad{ }^{4}$ Soft, sticky, glossy. 
Experiment No. 4.-Residual asphaltic petroleum-Hot application.

Location: From station $209+00$ to station $280+00$.

Length: 7,100 feet.

Date of application: From October 9 to October 15.

Temperature of oil: Maximum $210^{\circ} \mathrm{F}$., minimum $165^{\circ} \mathrm{F}$, average $188^{\circ} \mathrm{F}$.

TABLe 24.-Analysis of residual asphaltic petroleum ${ }^{1}$ used in experiment No. 4.

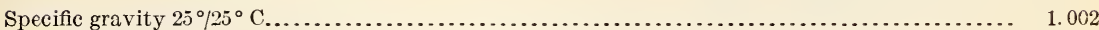

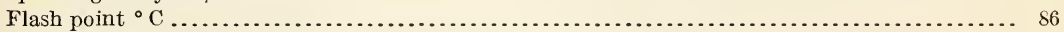

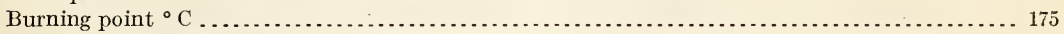

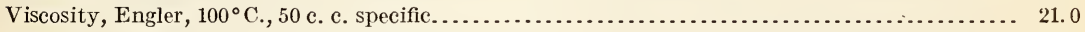

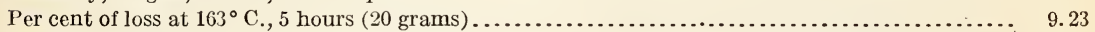

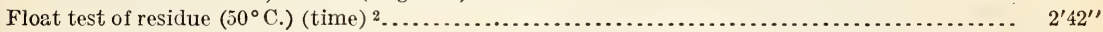

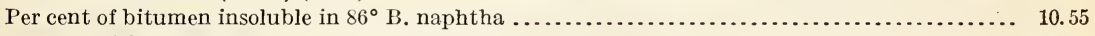

Per cent of fixed carbon. . . . . . . . . . . .

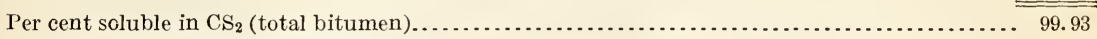

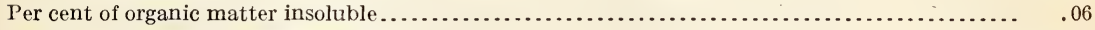

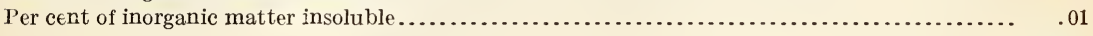

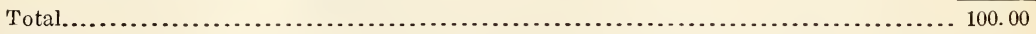

Details.-From station $241+50$ to station $251+07$ the macadam was first well sprinkled with water and the oil was applied while the road surface was still moist. Owing to the viscosity of the oil and the cool weather, some difficulty was experienced in starting the distributor pump. This resulted in the formation of pools of thick oil at the beginning of each trip before the nozzles worked uniformly enough to have the team start. After a few experiences with this trouble, the distributor nozzles were allowed to discharge into the ditch until a uniform distribution began.

Experiment No. 5.-Residual asphaltic petroleum-Hot application.

Location: From station $280+00$ to station $347+75$.

Length: 6,775 feet.

Date of application: From October 21 to November 21.

Temperature of oil: Maximum $221^{\circ} \mathrm{F}$., minimum $167^{\circ} \mathrm{F}$., average $200^{\circ} \mathrm{F}$.

TABLE 25.-Analysis of residual asphaltic petroleum ${ }^{1}$ used in experiment No. 5 .

\begin{tabular}{|c|c|c|}
\hline & Car No. 1 & Car No. 2. \\
\hline 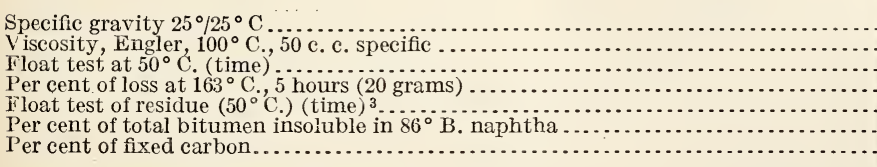 & $\begin{array}{c}0.990 \\
26.0 \\
1^{\prime} 28^{\prime \prime} \\
3.03 \\
2^{\prime} 50^{\prime \prime} \\
19.29 \\
10.47\end{array}$ & $\begin{array}{c}0.998 \\
37.5 \\
1^{\prime} 26^{\prime \prime} \\
2.63 \\
2^{\prime} 45^{\prime \prime} \\
18.83 \\
10.64\end{array}$ \\
\hline 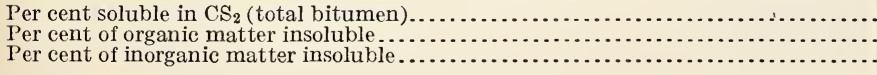 & $\begin{array}{r}99.97 \\
.02 \\
.01\end{array}$ & $\begin{array}{r}99.90 \\
.10 \\
.00\end{array}$ \\
\hline Total & 100.00 & 100.00 \\
\hline
\end{tabular}

I Sticky, viscous fluid.

2 Sticky, semisolid.

${ }^{3}$ Soft, sticky. 
Detaits.-Car No. 1 began to foam badly from water contamination after the first two loads had been applied. About 2,000 gallons were used, when, owing to the difficulty of handling the material, tho remainder of the shipment was rejected and replaced by car No. 2 . From station $314+10$ to station $320+70$ and from station 294 to station 308 the oil was applied soon after a rain while the surface of the macadam was still moist.

Experiment No. 6.- Water-gas tar preparation-Hot applicatiox.

Location: From station $34 i+75$ to station $411+00$.

Length: 6,325 feet.

Date of application: November 24 and Norember 26.

Temperature of tar: Maximum $248^{\circ} \mathrm{F}$; minimum $180^{\circ} \mathrm{F}$; average $214^{\circ} \mathrm{F}$.

TABLE 26.-Analysis of water-gas tar preparation ${ }^{1}$ used in experiment No. 6 .

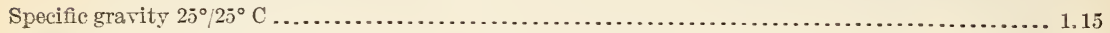

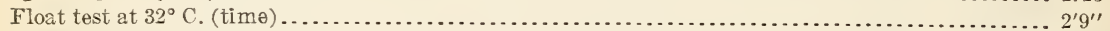

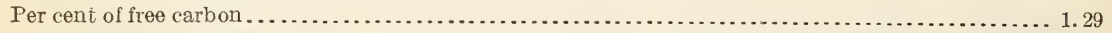

Distillation: $\quad$ By rolume. By weight.

Water......................................................... $0.0 \quad 0.0$

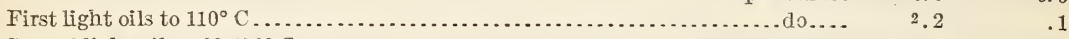

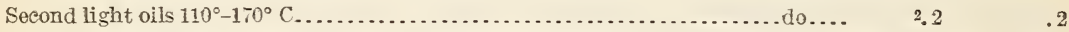

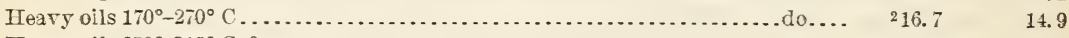

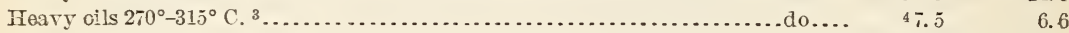

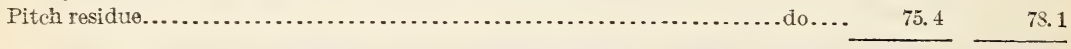

Total .......................................................

Details. - The east half of the road from station $393+60$ to station $397+60$ was treated by means of hand-pouring pots.

Experiment No. 7.-Asphaltic petroleuli-Cold application.

Location: From station $411+00$ to station $477+89$.

Length: 6,689 feet.

Date of application: December 4 and 5 .

Temperature of oil: From $80^{\circ}$ to $100^{\circ} \mathrm{F}$.

TABLE 27.-Analysis of asphaltic petroleum ${ }^{5}$ used in experiment No. 7.

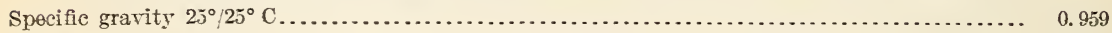

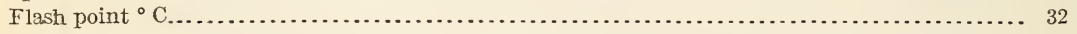

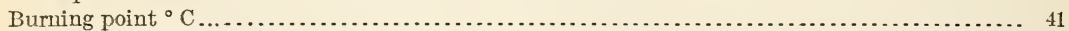

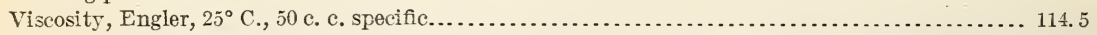

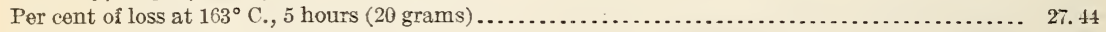

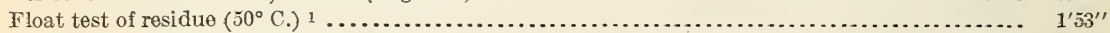

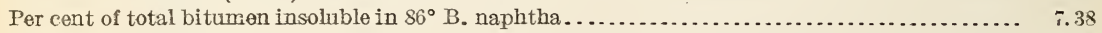

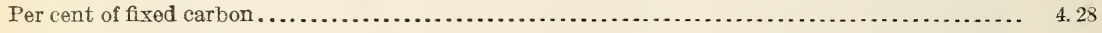

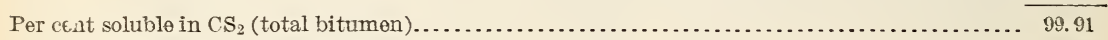

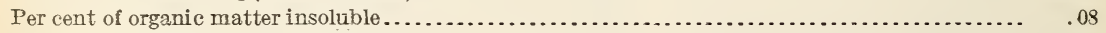

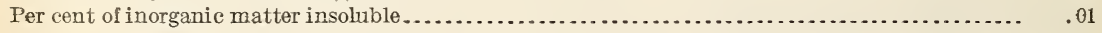

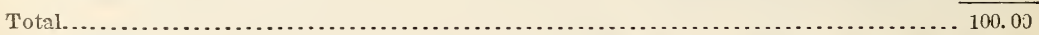

1 Sticky, very viscous fluid.

${ }_{3} \mathrm{~A} 315^{\circ}-350^{\circ} \mathrm{C}$. fraction showed 5 per cent and a $350^{\circ}-375^{\circ} \mathrm{C}$. fraction showed 10 per cent insoluble in dimethyl sulphate.

4 Clear; showed 5 per cent insoluble in dimethyl sulphate.

5 Sticky, fluid, with strong naphtha odor. 
The cost data given in Table 28 are based upon the following unit prices for labor and materials:

Foreman (per 8-hour day).

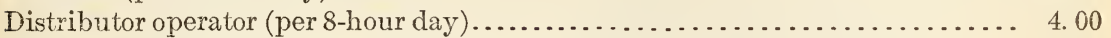

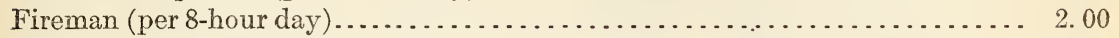

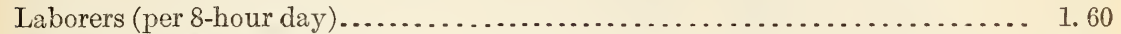

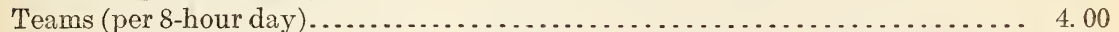

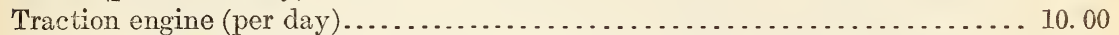

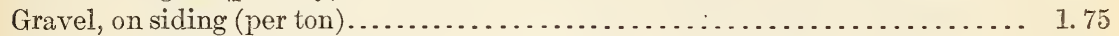

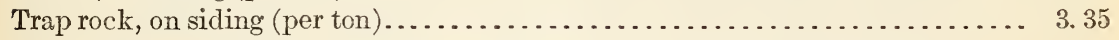

No charge was made for distributor or other implements.

TABLE 28.-Materials and cost data for surface treatment experiments on Rockville Pike.

\begin{tabular}{|c|c|c|c|c|c|c|c|c|c|c|c|c|c|c|c|}
\hline \multirow[b]{2}{*}{ 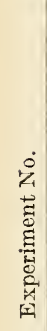 } & \multicolumn{3}{|c|}{ Description. } & \multicolumn{2}{|c|}{$\begin{array}{c}\text { Quantity } \\
\text { of ma- } \\
\text { terials } \\
\text { (per square } \\
\text { yard). }\end{array}$} & \multicolumn{8}{|c|}{ Cost per square yard. } & \multicolumn{2}{|c|}{ Total cost. } \\
\hline & $\begin{array}{l}\text { Bituminous } \\
\text { material. }\end{array}$ & 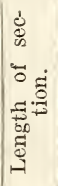 & 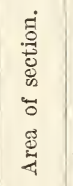 & 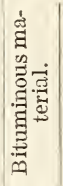 & 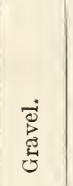 & 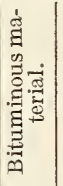 & 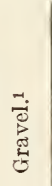 & 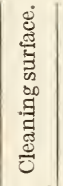 & 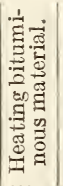 & 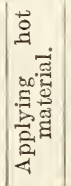 & 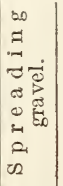 & 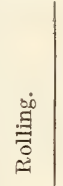 & 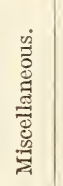 & 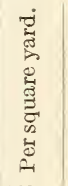 & 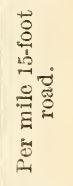 \\
\hline 1 & $\begin{array}{l}\text { Refined coal tar } \\
\text { (hot) }\end{array}$ & Feet. & $\begin{array}{c}S q q . \\
y d s \\
10,175\end{array}$ & $\begin{array}{l}\text { Gal- } \\
\text { lons. } \\
\text {. } 531\end{array}$ & $\begin{array}{c}C u . \\
y d s . \\
0.0138\end{array}$ & $\begin{array}{l}\text { Cts. } \\
4.35\end{array}$ & $\begin{array}{l}\text { Cts. } \\
3.01\end{array}$ & $\begin{array}{l}\text { Cts. } \\
0.30\end{array}$ & $\begin{array}{l}\text { Cts. } \\
1.22\end{array}$ & Cts. & $\begin{array}{l}\text { Cts. } \\
0.55\end{array}$ & $\begin{array}{l}C t s . \\
0.05\end{array}$ & $\begin{array}{l}\text { Cts. } \\
0.92\end{array}$ & $\begin{array}{l}\text { Cts. } \\
10.93\end{array}$ & $\$ 961.84$ \\
\hline 2 & $\begin{array}{l}\text { Refined water-gas } \\
\operatorname{tar}(\operatorname{cold}) . . .\end{array}$ & 38 & 12,300 & .438 & .0138 & 2.85 & 3.01 & .30 & .09 & .37 & .55 & .05 & .92 & 8.14 & 716.32 \\
\hline 3 & $\begin{array}{l}\text { Asphaltic petrole- } \\
\text { wn (cold) }\end{array}$ & in & 12,333 & 470 & .0138 & 2.35 & 3,01 & 30 & .09 & 37 & 5. & 0.5 & 92 & 7.64 & 672,32 \\
\hline 4 & $\begin{array}{l}\text { Residual asphatic } \\
\text { petroleum (hot) }\end{array}$ & 7.100 & 11,833 & .473 & .0138 & 3.29 & 3.01 & 80 & 1.22 & 53 & .55 & .05 & .92 & 9.87 & 868 \\
\hline ? & Do .............. & 6,77 & 11290 & .496 & .0138 & 3.31 & 3. 01 & .30 & 1. 22 & .53 & .55 & .05 & .92 & 9.89 & 870.32 \\
\hline & cnhalt & & 10,542 & .531 & .0138 & 3. 72 & 3.01 & .30 & 1. 22 & .53 & .55 & .05 & .92 & 10.30 & 906.40 \\
\hline & um (cold) & & 1.148 & .502 & .0138 & 3.33 & 3. 01 & .30 & .09 & .37 & .55 & .05 & .92 & 8. 62 & 758.56 \\
\hline
\end{tabular}

1 The costs in this table are based on finishing with gravel. The trap-rock screenings were applied at the rate of 0.0132 cubic yard per square yard at an additional cost of 2.82 cents per square yard, or $\$ 218.16$ per mile of 15 -foot road.

\section{SUMMARY OF EXPERIMENTS ON ROCKVILLE PIKE.}

These experiments were carefully inspected on January 7 and again on April 2, 1914. It is, of course, too early to draw any conclusions regarding the relative value of the several treatments. From a consideration of the present condition of all the sections, it would appear that the trap rock and gravel have given equally good results. Experiment No. 1, which has been under traffic the longest, has developed a smooth, firm surface with but few defects, and these are slight. There has been, however, a decided settlement of the road along the west shoulder in the vicinity of station $12+00$, and this has resulted in the surface breaking along the edge. Experiment No. 2 has also developed a generally smooth surface. Toward the north end of this experiment, the surface treatment has worn 
off to some extent, yielding a mosaic appearance, but, owing to a fair penetration obtained with the material used, the stones are held firmly in place by a matrix of fine stone and bitumen. Experiment No. 3 has a more rubbery or corky character than any of the others, and shows some tendency to become muddy during long periods of rain or snow. This tendency is still more pronounced on experiment No. 7, but the surfaces of both experiments soon become smooth and perfect with the advent of dry weather. Evidences of frost action and a consequent heaving of the surface were noted between station $164+00$ and station $167+00$. Between station $156+50$ and station $157+50$ a 24 -inch culvert running diagonally under the road broke through. This has been replaced with new pipe, and the road will necessarily be resurfaced over the area involved. The surfaces of experiments Nos. 4, 5, and 6 are in general smooth and firm throughout. There is, perhaps, more unevenness throughout experiment No. 5, owing largely to the fact that the treatment was so interrupted because of the difficulties incident to handling the tank car of foaming material. The surface of experiment No. 6 has picked off in a number of small areas throughout the crown of the road, and will require immediate repair at these points. These defects evidently developed through insufficient protection of the bituminous surface with screenings or gravel. There has apparently been some settlement in the wheel tracks throughout experiment No. 7 and to some extent on experiment No. 6.

Beginning with June 28, 1913, regular counts of traffic on Rockville Pike were made every 13 days for a 24 -hour period. A tabulation of the maximum and average of each class of traffic for 22 counts, covering the period from June 28, 1913, to March 28, 1914, is given in Table 29.

TABLE 29.- Tolume and character of traffic on Rockville Pike at its intersection with Bradley Lane.

\begin{tabular}{|c|c|c|c|c|}
\hline Vehicle. & $\begin{array}{l}\text { North- } \\
\text { bound. }\end{array}$ & $\begin{array}{l}\text { South- } \\
\text { bound. }\end{array}$ & $\begin{array}{l}\text { North- } \\
\text { bound. }\end{array}$ & $\begin{array}{l}\text { South- } \\
\text { bound. }\end{array}$ \\
\hline
\end{tabular}




\section{EXPERIMENTS AT MIAMI, FLA.}

\section{OILS-CORALLINE ROCK.}

These experiments are located on the Biscayne Drive about 2 miles north of Miami, Fla. This road is the principal highway connecting Miami with Fort Lauderdale, Palm Beach, and other cities along the Florida east coast and is subjected to a fairly heavy mixed traffic, with numbers of automobiles during the winter season. Like most of the roads in Dade County, it is surfaced with a soft oolitic limestone formed from coral remains and known locally as marl or coralline rock. Deposits of this material are found in abundance throughout the county, and it comes from the pit in a soft, usually moist condition somewhat resembling coarse gravel with a large proportion of fine material. It varies from pure white to rusty yellow in color. Upon exposure to the atmosphere and traffic on the road, it shows remarkable cementing qualities, becoming fairly hard, dense, and impervious, and, when used in newly constructed roads, it yields a smooth excellent surface at a comparatively low cost. These roads, however, wear rapidly and very unevenly, and potholes develop to such an extent and size as to make the surface rough and unsatisfactory for travel. To avoid this condition persistent maintenance by patching or the frequent resurfacing of the road is necessary and this is accomplished by scarifying the surface, recrowning, and rolling. The intense white color of the road surface also offers some objection on account of its trying effect on the eyes, and several unsuccessful efforts at surface treatment with bituminous materials have been tried for the double purpose of preserving the road and producing a more satisfactory color. A study of the general nature of the coralline rock led to the belief that a more satisfactory and permanent surfacing might be obtained in construction with a properly selected bituminous binder, and the following experiments were instituted in cooperation with the commissioners of Dade County, beginning with station 0 at the Miami end of the work. The experiments were begun on June 9, 1913, and completed on June 28, 1913.

The equipment consisted of a 10-ton gasoline roller, scarifier, grader, two 1-barrel heating kettles, and hand-pouring pots. The oil was in all cases applied by pouring pots. The sand used in finishing the surface was a very fine, white siliceous pit sand, which was screened for the purpose of removing twigs, leaves, and other foreign matter. Two asphaltic oils, one light and the other heavy, were used, and the characteristics of each are shown in the following table. The light oil was used without heating and the heavy oil was applied at a temperature of about $200^{\circ} \mathrm{F}$. 
TABLE 30.-Analysis of asphaltic petroleums used in experiments at Miami, Fla.

\begin{tabular}{|c|c|c|}
\hline \multirow[b]{2}{*}{ Character. } & Light. & Heary. \\
\hline & $\begin{array}{l}\text { Experi- } \\
\text { ments } \\
1,2,4\end{array}$ & $\begin{array}{l}\text { Experi- } \\
\text { ments } \\
3,5,6\end{array}$ \\
\hline 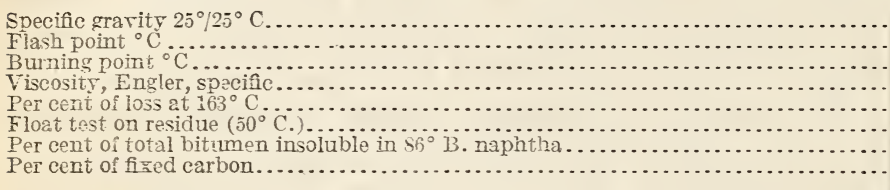 & $\begin{array}{r}0.960 \\
+2 \\
67 \\
1152.4 \\
27.53 \\
32^{\prime} 19^{\prime \prime} \\
10.40 \\
5.01 \\
\end{array}$ & $\begin{array}{l}0.992 \\
105 \\
145 \\
29.0 \\
16.33 \\
32^{4} 40^{\prime \prime} \\
10.83 \\
5 . \$ 2 \\
\end{array}$ \\
\hline 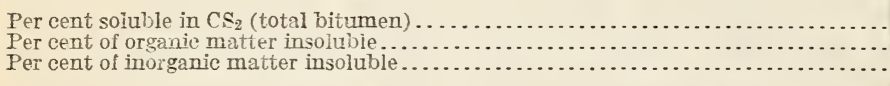 & $\begin{array}{r}99.04 \\
.05 \\
.00\end{array}$ & $\begin{array}{r}99.94 \\
.04 \\
.02\end{array}$ \\
\hline Total... & 100.00 & 100.00 \\
\hline
\end{tabular}

1 Ai $25^{\circ} \mathrm{C}$, $50 \mathrm{c.c}$.

2 At $100^{\circ}$ C., 100 c. c.

${ }^{3}$ Soft, sticky, with slight flow.

Experment No. 1.-Semipenetration Method-Cold, Light oil.

Location: From station $0+00$ to station $0+96$.

Length: 96 feet.

Method.-The old surface was scarified, regraded, and left loose to a depth of about 2 inches. Rain during the night previous to oiling caused the surface to rebond, and it was again broken to a depth of 2 inches and smoothed with rakes. The light oil was applied at the rate of 0.9 gallon per square rard and allowed to soak in for two hours before sanding, after which the surface was rolled. Owing to the quantity of fine material in the scarified surface, very little penetration was accomplished, but the oil was absorbed to a considerable extent. On rolling, the surface cracked and waved badly. Sereral rains with a light rolling after each improred its condition to a great extent, but the promise of ultimate success was not great.

Expernient No. 2.-Surface treatuent-Cold, light oil.

Location: From station $0+96$ to station $5+49$.

Length: 453 feet.

Method.-The old surface was scarified, regraded, and water-bound. It was then swept clean and the oil was applied at the rate of 0.5 gallon per square yard by means of pouring pots. After vigorously brooming the oil, the surface was sanded and rolled.

From station $0+96$ to station $2+85$ the surface was very damp from rain the previous night. The oil was allowed to stand from two hours at station $0+96$ to six hours at station $2+85$. It was sanded late in the afternoon and rolled the following morning. From station $2+85$ to station $3+90$ the sand was spread immediately after the oil was applied. From station $3+90$ to station $5+49$ the oil stood from three to six hours before sanding. The sanding was barely com- 
pleted when a heavy rain $f$ ell and on the following morning the sand mat was found washed into ridges and to a large extent carried off the road entirely. The portion of the experiment on which the oil had stood the shorter time became rather mushy and uneven, while the remainder of the section was fairly smooth and hard. The section was resanded but the same condition was evident two weeks later.

Experiment No. 3.-PENetration Method-Hot, HeAvi orl.

Location: From station $5+49$ to station $7+49$.

Length: 200 feet.

Method.-In this experiment, after the old surface had been regraded, a course of new unscreened rock was spread to a loose depth of $2 \frac{1}{2}$ inches. This course was brought to the required shape with a very light rolling in an effort to permit penetration by leaving the crust as open as possible. Light rains previous to the application of oil caused the surface to become slightly water-bound. The hot oil was applied at the rate of approximately 0.6 gallon per square yard, but owing to the varying texture of the surface it readily penetrated on some areas and remained almost entirely on the surface of others. The surface was sanded and rolled as in the previous experiments.

Experiment No. 4.-Penetration method-Cold, light oll.

Location: From station $7+49$ to station $9+16$.

Length: 167 feet.

Method.-This experiment was quite similar to No. 3 , in that the application was made on a $2 \frac{1}{2}$-inch course of new, unscreened rock. The rock was, however, heavily rolled in an effort to tighten the surface sufficiently for brooming the oil. This was partially effected and the penetration seemed to be as good as in the more lightly rolled section. Oil was applied at the rate of 0.7 gallon per square yard and allowed to stand for three hours before sanding, and at the end of this time it was practically all absorbed.

Experiment No. 5.-Penetration method-Hot, heavy oll.

Location: From station $9+16$ to station $11+55$.

Length: 239 feet.

Method.- This experiment was essentially the same as experiment No. 4 except for the reason that the course of new, unscreened rock was reduced to a loose thickness of $1 \frac{1}{2}$ inches in an effort to reduce the cost of this type of experiment. From station $9+16$ to station $10+$ 87 sand was used for a top dressing. The surface cracked and lifted under rolling, and required patching in several spots a few days later. From station $10+87$ to station $11+55$ new rock screenings were used. for the top dressing. 
Experiment No. 6.-Penetration method-Hot, heavy oll.

Location: From station $11+55$ to station $12+62$.

Length: 107 feet.

Method.-Owing to the difficulty in securing a surface of uniform texture with unscreened rock, it was decided to lay a section with new, screened material. The rock furnished from the pit was passed over a $\frac{3}{8}$-inch screen and the material retained was spread to a loose depth of 3 inches on the regraded road surface. Oil was applied at the rate of about 1 gallon per square yard, and this was sufficient to flush the voids. The penetration was evidently about 2 inches in depth over the entire surface of the section. From station $11+55$ to station $11+80$ new rock screenings were used as a top dressing, and over the remainder of the section sand was used for this purpose.

\section{SUMMARY OF EXPERIMENTS AT MIAMI, FLA.}

An inspection of these experiments in December, 1913, showed Nos. 1 and 2 to be in very bad condition and demonstrated the impracticability of treating the original coralline rock roadway either by attempted penetration or strictly surface application of bitumen. Experiments Nos. 3 and 4 presented a very satisfa tory appearance and there was little difference between them. No real failures were evident. Experiment No. 5 was not as satisfactory, although only two or three small holes had developed in it. Experiment No. 6 , where new, unscreened rock was used, was in excellent condition and showed no indication of weakness anywhere on its surface. The cross section was true throughout and it had not worn perceptibly, although the untreated road immediately north of it had worn fully an inch during the preceding six months.

The cost data are based upon the following unit prices for labor and materials:

Foreman (per 10-hour day)....... \$3.50

Rollerman (per 10-hour day)..... 4.00

Pit boss (per 10-hour day)....... 3.00

Labor (per 10-hour day).......... 1.50

Teams (per 10-hour day)........ 6.00

Rock, in pit (per cubic yard).... . 15
Screened rock............ $\$ 1.75$

Sand, on work............. 1.06

Light asphaltic petroleum (per gallon)..................... 162

Heavy asphaltic petroleum (per gallon)................. . 182

No charge was made for heating kettles, pouring pots, or other necessary equipment. 
TABLE 31.-Materials and cost data for experiments at Miami, Fla.

\begin{tabular}{|c|c|c|c|c|c|c|c|c|c|c|c|c|c|c|c|}
\hline \multirow[b]{2}{*}{ 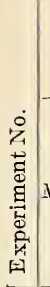 } & \multicolumn{4}{|c|}{ Description. } & \multicolumn{3}{|c|}{$\begin{array}{l}\text { Quantities of } \\
\text { materials (per } \\
\text { square yard). }\end{array}$} & \multicolumn{8}{|c|}{ Cost per square yard. } \\
\hline & Material and method. & 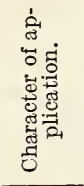 & 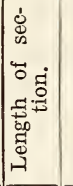 & 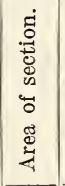 & 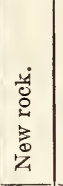 & 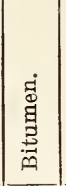 & $\begin{array}{l}\text { ठृं } \\
\text { कू } \\
\text { की }\end{array}$ & 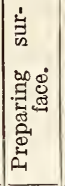 & 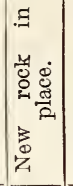 & 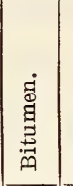 & 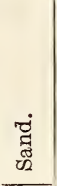 & 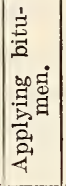 & 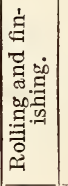 & 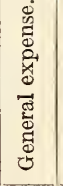 & 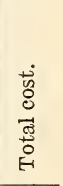 \\
\hline 1 & $\begin{array}{l}\text { Light asphaltic pe- } \\
\text { troleum (s e m i - }\end{array}$ & Cold.. & Feet. & $\begin{array}{c}S q . \\
y d s . \\
213\end{array}$ & $\begin{array}{c}C u . \\
y d s .\end{array}$ & $\begin{array}{l}\text { Gal- } \\
\text { lons. } \\
0.92\end{array}$ & $\begin{array}{c}\text { Cu. } \\
y d s . \\
0.012\end{array}$ & $\begin{array}{l}\text { Cts. } \\
2.34\end{array}$ & Cts. & $\begin{array}{r}\text { Cts. } \\
14.90\end{array}$ & $\begin{array}{l}\text { Cts. } \\
1.33\end{array}$ & $\begin{array}{c}C t s . \\
2.23\end{array}$ & $\mid \begin{array}{l}C t s . \\
1.01\end{array}$ & $\begin{array}{l}\text { Cts. } \\
0.98\end{array}$ & $\begin{array}{c}\text { Cts. } \\
22.79\end{array}$ \\
\hline 2 & $\begin{array}{l}\text { Light asphaltic pe- } \\
\text { troleum (surface }\end{array}$ & ...do... & 4531 & 1,006 & & .41 & .012 & 2.34 & & 6.66 & 1.33 & 1.01 & 1.01 & .98 & 13.33 \\
\hline 3 & $\begin{array}{l}\text { Heavy asphaitic pe- } \\
\text { troleum (p e ne }- \\
\text { tration method). }\end{array}$ & Hot... & 199 & 443 & 0.069 & .625 & .012 & 2.34 & 411.01 & 11.37 & 1.33 & 1.52 & 1.01 & .98 & 29.56 \\
\hline 4 & $\begin{array}{l}\text { Light asphaltic pe- } \\
\text { troleum (p en e- }\end{array}$ & Cold.. & 168 & 371 & .069 & .705 & .012 & 2.34 & 411.01 & 11.42 & 1.33 & 1.71 & 1.01 & .98 & 29.80 \\
\hline $\mathbf{b}$ & $\begin{array}{l}\text { Heavy asphaltic pe- } \\
\text { troleum (p en e - }\end{array}$ & Hot... & 239 & 531 & .041 & .62 & .012 & 2.34 & 46.61 & 11.28 & 1.33 & 1.51 & 1.01 & .98 & 25.06 \\
\hline 6 & ......do..................... & ...do. & 107 & 240 & .087 & .99 & .012 & 2.34 & 416.67 & 18.02 & 1.33 & 2.42 & 1.01 & .98 & 42. 77 \\
\hline
\end{tabular}

SUPPLEMENTARY REPORT OF EXPERIMENTS MADE AT WASHINGTON, D. C., 1912.

TAR PREPARATION AND OILS-SURFACE TREATMENT.

The original report of these experiments is to be found in Circular No. 99, and the following covers the repairs to date, and the condition of the various sections in January, 1914.

\section{Section No. 1.-Refined WATER-Gas tar PREParation.}

This section presents a smooth, hard, mosaic surface and has not required any repairs. In a few places along the sides of the road the treatment has cracked off for a few inches back from the edge, exposing the underlying macadam.

\section{Section No. 2.-Asphaltic petroleum.}

This treatment showed some tendency to push into slight waves and a few small humps, particularly along the south edge of the roadway. Several worn depressions in the middle of the road also developed during the winter, and apparently had their initial cause in the fact that small dust patches had been overlooked in cleaning the surface, and the treatment had not adhered properly. At the east end of the section, a number of steam pipes pass under the road, and the heat from these gives rise to conditions under which it has always been difficult to maintain a satisfactory road surface. Three distinct displacements of the surface have taken place at this point, 
resulting in the formation of depressions and corresponding humps. On July 11 the section was repaired and giren a light surface treatment with the material originally applied. The larger depressions were filled with 1-inch limestone and the water-gas tar preparation which had been used on section No. 1. The small depressions were filled with fine screenings and the oil originally used on this section. All humps were remored with a mattock. When such repairs had been made, oil was applied at the rate of 0.10 gallon per square yard throughout the most traveled area by allowing it to run from the bung of the barrel and distributing it with hand push brooms. The application was covered with a thin layer of torpedo sand.

The total cost of maintenance for the year was \$25.49, or 2.33 cents per square yard for the entire section.

When inspected in January, the general appearance of the surface was satisfactory, but the wearing carpet appeared to be developing numerous fine cracks throughout the entire length. The portion over the steam pipes required further repair in the early winter, and a change in the form of construction at this point will probably be made.

\section{Section No. 3.-Residual petroleun.}

As noted in Circular No. 99, this section showed a tendency to become muddy in wet weather, and after periods of continued rain the surface was corered with a deep oily mud, which traffic gradually worked into low ridges along the edges of the road. By summer the surface of the macadam began to be exposed throughout the traveled way, and a light treatment with the oil originally used was made on July 9, 1913. The oil was applied at the rate of about 0.10 gallon per square yard throughout the most traveled area in the same manner as on section No. 2 and was corered with torpedo sand.

The total cost of this work was $\$ 20.65$, or 2.92 cents per square yard, for the entire section.

The section now presents a generally satisfactory appearance excepting for a small area on the grade at the west end. The treatment is largely worn off here, but this is almost entirely due to the condition of the adjoining parement and gutter, where water is held for some time after a storm and continually carried on the oiled section by traffic.

\section{Section No. 4.-Asphaltic Petroleum.}

This surface gave excellent service in both wet and dry weather, but, owing to the light treatment which had been giren, it gradually wore off until the underlying macadam was exposed in places throughout the traveled way. A second application of about 0.10 gallon per square yard of the oil originally used was made in July, 1913, 
throughout the most traveled area. The oil was applied in the same manner as on the two previous sections and covered with torpedo sand.

The east arm of the fork at the north end of the section was not treated at this time, owing to the fact that traffic through there had not been sufficient to crush the gravel covering completely. The surface treatment, however, had by winter disappeared over an area of about 4 square yards, and in December this place was patched with a surface application of oil and fine gravel.

The total cost of maintaining this section was $\$ 27.45$, or 2.08 cents per square yard, for the entire section. When last inspected it presented a smooth, uniform surface throughout.

\section{SUPPLEMENTARY REPORT OF EXPERIMENTS AT CHEVY CHASE, MD., 1911 PROJECT.}

BITUMINOUS CONSTRUCTION AND SURFACE TREATMENT.

The original reports of these experiments are given in Circulars Nos. 98 and 99 . The following report is based upon an inspection made January 29, 1914:

Section No. 1.-Reflned coal tar-Penetration method.

The surface of this section is well bound and presents as a whole a satisfactory appearance, but the seal coat is worn off to the extent of about 75 per cent and a few shallow, worn depressions can be noted. It was decided that a new seal coat was not necessary at the beginning of the past season, but an application of a light tar and screenings will very likely be made in the spring.

Section No. 2.-Refined coal tar-Modified Gladwell method.

The surface of this section is well bound and its general appearance is good excepting for a slight unevenness. This is to be expected from the excessive bleeding which originally took place and the necessary irregularity in the distribution of chips to take up the bitumen.

Section No. 3.-Fluxed Native asphalt-Penetration method.

This section continues to present an excellent appearance. The seal coat as a whole is intact excepting for a few small areas which present a somewhat mosaic appearance. No holes or depressions are in evidence and the section has had no repairs to date.

Section No. 4.-Gilsonite oil asphalt-Penetration method.

As a whole this section continues in good condition and, excepting for a slight unevenness, the surface presents a satisfactory appearance. There are, however, a few places where the coarse stone shows 
up rather unevenly, and this condition led to the formation of a number of worn depressions toward the north end of the section, where patching became advisable. The shallower places were cared for by a thin paint coat of oil asphalt with screenings, but a few of the deeper ones were cut out clean and filled with new stone, and a patch was made by the penetration method.

The total cost of patching during the past year was $\$ 4.05$.

Section No. 5.-Oil asphalt-Penetration method.

During the past summer it became necessary to repair four small worn depressions in which the stones were working loose. Three were on the east side and one was on the west side of the road, and all were close to the gutter. At the time of the inspection the surface presented a somewhat uneven and worn appearance; coarse surface stones were in evidence throughout, and the binder apparently did not retain much life. There were, however, no signs of raveling and no necessity for any repairs.

The total cost of patching during the past year was $\$ 2.31$.

Section No. 6.-Oil asphalt-Penetration method.

This section presents about the same general appearance as No. 5 . The depressions mentioned in the previous inspection report raveled badly in a few months and were finally repaired with new stone and oil asphalt applied by the penetration method. Four patches were made along the west side close to the gutter and one at the north end of the east side.

The total cost of these repairs was $\$ 3.47$.

Section No. 7, A and B.-Oil asphalt-Penetration method.

The bitumen used in this section was without doubt too hard and had too high a melting point for this class of construction. In $A$, where two coats were applied, the binder lacks life, and it became necessary to patch another loose depression during the past season. $B$ offers an excellent demonstration of what prompt and efficient maintenance can accomplish when the failure of bituminous construction is imminent. The simple cold-surface treatment described in Circular No. 99 undoubtedly prevented the loss of this section, and it now presents a good surface. It has had no further attention and, with the exception of one or two very small worn places which were evidently not properly cared for when repairs were made, it will probably not require any expenditure upon it during the coming season. 
Section No. 8.-Piefined water-gas tar Preparation-Surface treatment.

During the spring of 1913 the first surface treatment began to lose its efficiency on this section and a number of small, shallow chug holes developed, particularly toward the north end. In order to prevent further deterioration, these were repaired with a light application of heavy refined coal tar and fine gravel. On September 12,1913 , the section was given a surface treatment of the same trade product which was originally used, the analysis of which is shown in the following table:

TABLE 32.-Analysis of refined water-gas tar ${ }^{1}$ used in second surface treatment of section No. 8 .

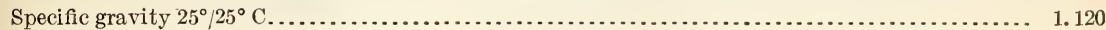

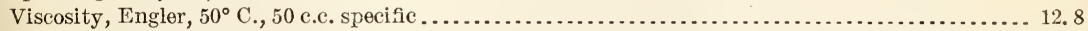

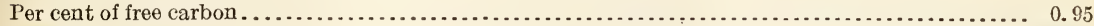

Distillation: $\quad$ Byvolume. By weight.

Water................................................per cent.. . $0.2 \quad 0.2$

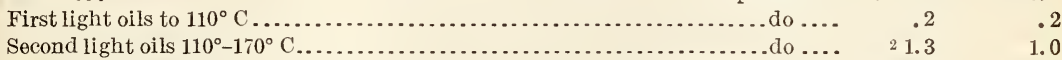

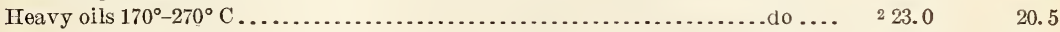

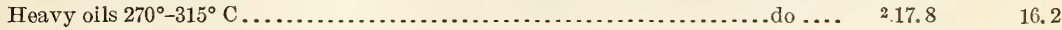

Pitch residue.................................................. $\quad 57.5 \quad 61.8$

Total........................................................ $100.0 \quad 99.9$

The surface was swept and the material was applied by an automobile distributor and was charged at 9 cents per gallon distributed on the cleaned road. The application was immediately covered with clean limestone screenings of a size that would pass a 1-inch screen, and lightly rolled. The cost data for this treatment are given in Table 34. The section now offers a fairly uniform, attractive surface, well bound and comparatively free from ruts or depressions.

Section No. 9.-Asphaltic petroleum-Surface treatment.

This section, like section No. 8 , began to lose the effect of its first treatment in the spring of 1913. The deterioration was most marked on the outer third of the road adjacent to the gutter, where traffic was lightest. This was evidently due to the fact that the surface lacked the ironing action of traffic and, lying somewhat open and porous, was rutted by the combined action of water and detritus. which worked over upon it. A number of shallow, worn depressions developed, principally at the south end of the section. These were filled by applying a hot paint coat of the oil asphalt used in section No. 5 and then filling the depression with clean 1-inch limestone screenings.

On July 30 and 31, immediately after these patches had been made, the entire section was given a surface treatment of the same trade 
product originally used and was then covered with a layer of clean limestone screenings which would pass a 1-inch screen. The surface was first swept by hand push brooms, and the oil was applied by allowing it to run from the bungs of the barrels and distributing it with brooms. The surface was not rolled. A torrential rain interrupted the work when the south half of the section had been completed. Some of the oil was washed into the gutters and this is no doubt responsible for the fact that the southern end of the section now presents a rougher appearance than the north half.

Table 33 shows the characteristics of the bituminous material used.

TABLE 33.-Analysis of asphaltic petroleum ${ }^{1}$ used in second surface treatment of section No. 9.

Specific gravity $25^{\circ} / 25^{\circ} \mathrm{C}$ 0.959

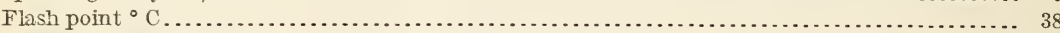

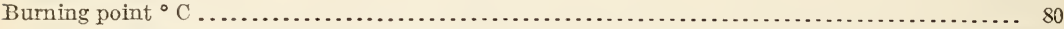

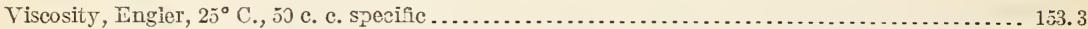

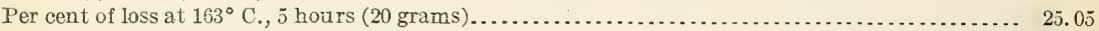

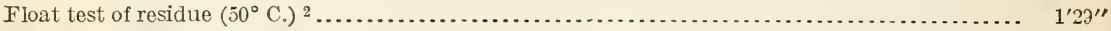

Per cent of total bitumen insoluble in $86^{\circ} \mathrm{B}$. naphtha. . . . . . .

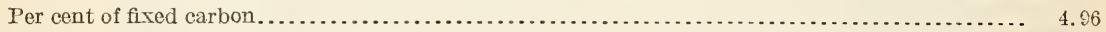

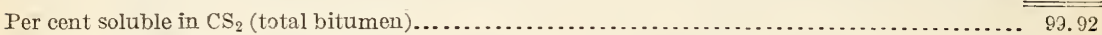

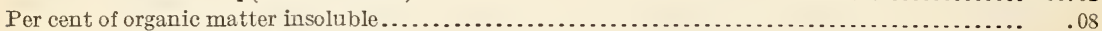

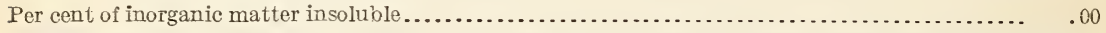

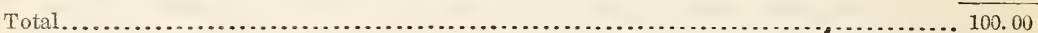

The materials and cost data for the second surface treatment of sections Nos. 8 and 9 are given in Table 34, as follows:

TABLE 34.-Waterials and cost data for second treatment of sections Nos. 8 and 9.

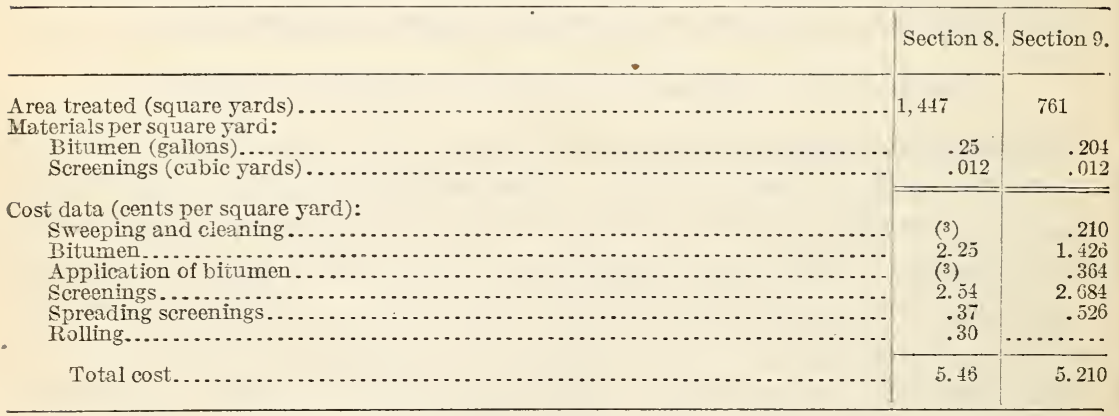

Section No. 10.-Residual Petroleum-Surface treatalent.

As had been anticipated, this section began to bleed excessively with the advent of warm weather and required the application of approximately 4 cubic yards of limestone screenings to prevent the surface from picking up. The surface also began to wave badly, 
developing irregular humps throughout the entire length of the section, which in places were easily 3 inches above the actual cross section of the road. To remedy this condition the humps were either trimmed off or entirely removed with a shovel until the clean macadam stone was exposed. The material thus removed was generally quite rich in bitumen and was distributed where required in order to improve the cross section of the surface. These fresh patches were protected by a thin covering of screenings, and they held in place well, so that at the time of inspection the section presented a much improved and fairly uniform appearance.

The cost of maintenance on this section for the year amounted to $\$ 19.05$, or 1.88 cents per square yard for the entire section.

Section No. 11.-Native asphalt Emulsion-Macadam Resurfacting.

No further treatment has been given to this section, and it presents a smooth, firm, and satisfactory appearance. Owing to the omission of any finishing coat of bituminous material, there were two smail areas on the east side near the north end in which the coarse stone could be seen. These did not ravel or wear appreciably, but in conjunction with other repairs they were recently painted with a thin coat of cold refined water-gas tar preparation and covered with a light scattering of screenings.

\section{SUPPLEMENTARY REPORT OF EXPERIMENTS MADE ON BRADLEY LANE, CHEVY CHASE, MD., 1911.}

REFINED SEMIASPHALTIC OIL.

The original report of these experiments was published in Circular No. 98, and the report of an inspection at the end of a year's service may be found in Circular No. 99. The following report covers the condition of the experiment at the end of 1913, and the repairs up to date.

The surface treatment of Bradley Lane was originally treated as three distinct experiments, but owing to the fact that the conditions on all three sections have become, in general, the same, they will be considered as a unit. The formation of a thick mat or hump on the outer edges of the roadway where the heavier treatment had been applied was noted in Circular No. 99. The wear throughout the entire traveled way became more pronounced during the past year; the surface was exposed in long shallow depressions of varying length; and a number of depressions ranging in depth from 1 to 2 inches developed. It was found that the mat along the sides was rich in bitumen which still possessed good adhesive qualities, and the mixture was therefore used for filling the worst depressions. When tamped into place and covered with a thin layer of screenings, a satisfactory and firm patch soon resulted through compression by traffic. By 
thus trimming off the humps and filling depressions the general contour of the road was greatly improved. In December all bare places were corered with a light application of the water-gas tar preparation No. 1 the analysis of which is giren in Table 2, and screenings.

The total cost of maintaining and repairing the surface during the yèr was $\$ 40.41$, or 1.19 cents per square Jard for the entire area.

\section{SUPPLEMENTARY REPORT OF EXPERIMENTS MADE AT JAMAICA, N。Y,} 1911.

OIL-CEMENT CONCRETE, OIL ASPHALT, TAR, AND FLUXED NATIVE ASPHALT.

The original report of these experiments was published in Circular No.99, and the report of an inspection made December 19, 1912, with repairs to date, was given in Circular No. 99. The experiments were again inspected and repaired in June, 1913, and the following report covers the work done at that time and the condition of the sections when again inspected on December 16, 1913.

\section{Experiment No. 1.-OiL-Cement concrete.}

When inspected in June it was found that practically all of the various carpet coats which were applied to this section in 1912 were gone with the exception of the refined coal-tar section. About 75 per cent of the carpet coat on this section was in fair condition.

The surface of the parement showed the effect of the wear of traffic and contained many shallow depressions among which the following were so deep as to be practically through the concrete: Station $0+98$, 4 feet by 5 feet, again the south side of the parement; station $0+$ $75,2 \frac{1}{2}$ feet by 3 feet, 8 feet from the south edge of the parement; station $0+7 i, 1$ foot by $1 \frac{1}{2}$ feet, 13 feet from the south edge of the parement; station $0+77,1 \frac{1}{2}$ feet by $1 \frac{1}{2}$ feet, 16 feet from the south edge of the parement; station $0+03,2 \frac{1}{2}$ feet by 4 feet, $1 S$ feet from the south edge of the parement.

The expansion joint at station $0+97$ was in perfect condition and had completely protected the abutting ends of the concrete.

Repairs were made as follows: The entire section was gone orer and all the old flush coat that could be loosened readily with pick and shorel was remored. The shallow depressions, 1 to $1 \frac{1}{2}$ inches in depth, were filled to grade with $\frac{3}{4}$-inch stone. The deep depressions were cut out to the subgrade to the size abore stated and filled with $1 \frac{1}{2}$-inch stone, the voids of which were filled with sand and refined coal tar. The depression at station $0+03$ was repaired with paving: brick. The entire section was then surface-treated with bituminous materials as follows: From station $0+00$ to station $0+57$, refined coal tar, 0.30 gallon per square yard; from station $0+57$ to station $0+97$, water-gas tar preparation No. 1, 0.44 gallon per square yard; and from station $0+97$ to the east end of the section, water-gas 
tar preparation No. 2, 0.41 gallon per square yard. Sand was spread over the flush coat at the rate of 0.016 cubic yard per square yard. The joints in the paving brick patch were filled with sand. Table 35 gives the analyses of the bituminous materials used.

TABLE 35. - Analyses of tar products used in surface treatment of oil-cement concrete at Jamaica, N. Y.

\begin{tabular}{|c|c|c|c|c|c|c|}
\hline Materials. & \multicolumn{2}{|c|}{ Refined coal tar. } & \multicolumn{2}{|c|}{$\begin{array}{l}\text { Water-gas tar prep- } \\
\text { aration No. } 1 .\end{array}$} & \multicolumn{2}{|c|}{$\begin{array}{c}\text { Water-gas tar prep- } \\
\text { aration No. } 2 .\end{array}$} \\
\hline \multirow[t]{2}{*}{ 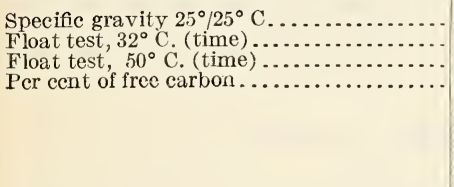 } & \multicolumn{2}{|c|}{$\begin{array}{l}1.209 \\
1^{\prime} 3^{\prime \prime} \\
17.08\end{array}$} & \multicolumn{2}{|c|}{$\begin{array}{c}\text { 1. } 172 \\
16^{\prime} 28^{\prime \prime} \\
2^{\prime} 18^{\prime \prime} \\
1.35\end{array}$} & \multicolumn{2}{|c|}{$\begin{array}{l}1.154 \\
3^{\prime} 20^{\prime \prime} \\
1^{\prime} 2^{\prime \prime} \\
1.45\end{array}$} \\
\hline & $\begin{array}{l}\text { By } \\
\text { volume. }\end{array}$ & $\begin{array}{c}\text { By } \\
\text { weight. }\end{array}$ & $\begin{array}{c}\text { By } \\
\text { volume. }\end{array}$ & $\underset{\text { weight. }}{\text { By }}$ & $\begin{array}{c}\text { By } \\
\text { volume. }\end{array}$ & $\underset{\text { weight. }}{\text { By }}$ \\
\hline \multirow[t]{2}{*}{ 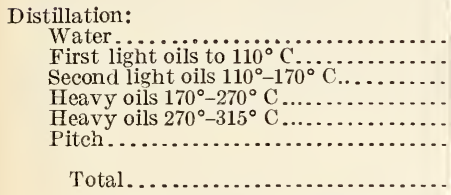 } & $\begin{array}{r}\text { Per cent. } \\
0.0 \\
1.4 \\
1.5 \\
317.9 \\
411.7 \\
69.5\end{array}$ & $\begin{array}{r}\text { Per cent. } \\
0.0 \\
.3 \\
.3 \\
14.7 \\
9.7 \\
74.7\end{array}$ & $\begin{array}{r}\text { Per cent. } \\
0.0 \\
2.5 \\
2.3 \\
22.3 \\
511.8 \\
85.1\end{array}$ & $\begin{array}{r}\text { Per cent. } \\
0.0 \\
.4 \\
.2 \\
1.8 \\
10.1 \\
87.4\end{array}$ & $\begin{array}{r}\text { Per cent. } \\
\text { Trace. } \\
21.2 \\
2.3 \\
25.4 \\
618.5 \\
74.6\end{array}$ & $\begin{array}{r}\text { Per cent. } \\
\text { Trace. } \\
0.9 \\
.2 \\
4.0 \\
16.2 \\
78.5\end{array}$ \\
\hline & 100.0 & 99.7 & 100.0 & 99.9 & 100.0 & 99.8 \\
\hline
\end{tabular}

6 Clear, showed 2.5 per cent insoluble in dimethyl sulphate.

When inspected in December, it was found that the part treated with refined coal tar was in slightly better condition than that treated with the water-gas tar preparation. Both sections showed similar bare spots, about the size of one's hand, where the tar carpet had been removed from the traveled way. The penetration patch in the center of the roadway west of the wood blocks was a trifie low, and tended to hold sand and dust, but the long patch just east of it on the south side of the roadway was in good condition.

\section{Experiment No. 2.-CUt-Back oll asphalt-Mixing Method.}

In June this experiment was in very fair condition for a width of about 12 feet through the center and for its entire width from station $4+50$ to the east end of the section. The sides of the road from station $1+98$ to station $4+50$ were rough, wavy, and badly worn, as noted in circular No. 99.

Repairs were made as follows: The entire surface of the section was broken up with a scarifier from the west end to station $4+50$. No particular difficulty was experienced in the scarifying, and the bituminous wearing course broke up into fairly small pieces. The bitumen seemed to have about the same consistency as when originally put into the road. After the road was scarified, the bituminous wearing course was further broken up with picks and shovels and spread 
to a uniform grade. The road was then well rolled. A seal coat of refined coal tar, the analysis of which is given in Table 35, was then applied at the rate of 0.53 gallon per square yard, covered immediately with $\frac{3}{4}$-inch stone at the rate of 0.024 cubic yard per square yard, and thoroughly rolled. The $\frac{3}{4}$-inch stone used was rather dirty, owing to haring been handled from the ground sereral times.

When inspected in December, this section was found to be in worse condition than before it had been scarified. Short, choppy wares had dereloped, from 3 to 4 feet in length and from 4 to 5 inches deep, from crest to trough. A somewhat wary condition had also developed on the north side from station $4+50$ to station $5+00$.

Experiment No. 3.-Fluxed native asphalt-Mixing Method.

To repairs were made to this section and when inspected in December it was still found to be in rery good condition. There was a slight indication of wariness, but the undulations were long and shallow, and not sufficiently pronounced to inconvenience automobile traffic.

Experiment Nö. 4.-Refined coal tar-Mixing Method.

No repairs were made to this section and when inspected in Decem= ber it was reported as being generally in good condition. The surface from station $8+00$ to station $8+70$ was rerr smooth, but some waviness had developed along the outer one-third of the roadway. On the south side this was apparently due to bleeding, and the excess material had been worked outward into waves which were in no place, however, more than 2 inches in depth. The earth shoulders along the brick gutters throughout this portion of the parement had been much eroded, and the water from the road surface and cross streets does not flow in the gutter but along the shoulder of this section. From station $8+70$ to station $9+50$ the surface condition is rery good and presents a somewhat mottled appearance, with about one-half mosaic and one-half covered with bitumen. From station $9+50$ to the end of the section, where the oil-asphalt seal coat was applied, the surface resembled sheet asphalt. This portion was becoming a trifle wary about midway between the sides and crown of the roadway.

Experinget No.5.-CUT-BACK OIL ASPHALT-Mixing Method.

In June the general surface of this section was good except that it had waved slightly on the sides and holes had been worn through as follows: Station $11+65,2 \frac{1}{2}{ }^{1}$ feet by $2 \frac{1}{2}$ feet at the north edge of the pavement; station $11+68,2$ feet by $2 \frac{1}{2}$ feet, 5 feet from the south edge 
of the parement; station $11+80,1 \frac{1}{2}$ feet by 2 feet, 7 feet from the south edge of the pavement; station $12+20,2$ feet by 2 feet, 7 feet from the south edge of the parement; station $12+48,3$ feet by 3 foet, 17 feet from the south edge of the parement; and station $13+67$, $1 \frac{1}{2}$ feet by $1 \frac{1}{2}$ feet, 17 feet from the south edge of the parement.

These holes were repaired by first digging out the wearing course and base to a depth of 4 inches. They were then filled with $1 \frac{1}{2}$-inch stone, and the voids of the stone were partially filled with sand and tamped by hand. The refined coal tar referred to in Table 35 was then applied, covered with $\frac{3}{4}$-inch stone, tamped by hand, and rolled with a steam roller.

When inspected in December it was found that two holes about 18 inches in diameter had worn almost through the thickness of the wearing surface. These were located on the north side of the road at station $11+6$ and station $11+22$, respectively. Between station $11+00$ and station $11+50$ a bad wary condition had dereloped on the north side of the road, but only to a slight extent on the south side. The center of the roadway was in very good condition. Sereral of the patches were low and all were in need of a seal coat, but the patch made with Topeka mixture was in excellent condition:

At Hardenbrook Avenue the south side of the intersection was more wavy than any other section of the experiments, excepting experiment No. 2, but the north side of the intersection was in very fair condition.

Experiment No. 6.-Oil asphalt-Penetration method.

No repairs were made to this section and it continues in excellent condition. Two grades of oil asphalt were originally used for a seal coat on this experiment, and the relative wearing qualities can now be noted. Where the heavier grade of material was used, the seal coat remains practically intact and only an occasional stone is visible. Many more stones of the wearing course can be seen where the lighter grade of the oil-asphalt seal coat was used.

Experiment No. 7.-REFined COAL tar-Penetration METHod.

In June this section was in good condition excepting that the following holes had worn through: Station $15+51,3 \frac{1}{2}$ feet by $3 \frac{1}{2}$ feet, at the north edge of the pavement; station $16+90,1$ foot by 4 feet, 1 foot from the south edge of the pavement; and station $16+95,1$ foot by $1 \frac{1}{2}$ feet, 1 foot from the north edge of the pavement. These holes were repaired in the same manner as those in section No. 5.

In December the section was reported as in good condition excepting for a raveled spot at station $16+50$.

Experiment No. 8.-Fluxed native asphalt-Penetration method.

No repairs were made on this section, and at the December inspection it was in good condition. 
Experiment No. 9.-OIL ASPhalt-Penetration inethod.

In June this section was in good condition with the exception of one hole $1 \frac{1}{2}$ feet by $1 \frac{1}{2}$ feet in size in the center of the road at station 18+50. This hole was repaired in the same manner as the holes in section No. 5 .

This section was in good condition in December, excepting for some bleeding and a slight waviness on the last 75 feet. This was, however, not sufficient to be noticeable to traffic.

TABLE 36.-Cost data of repairs at Jamaica, N. Y., 1913.

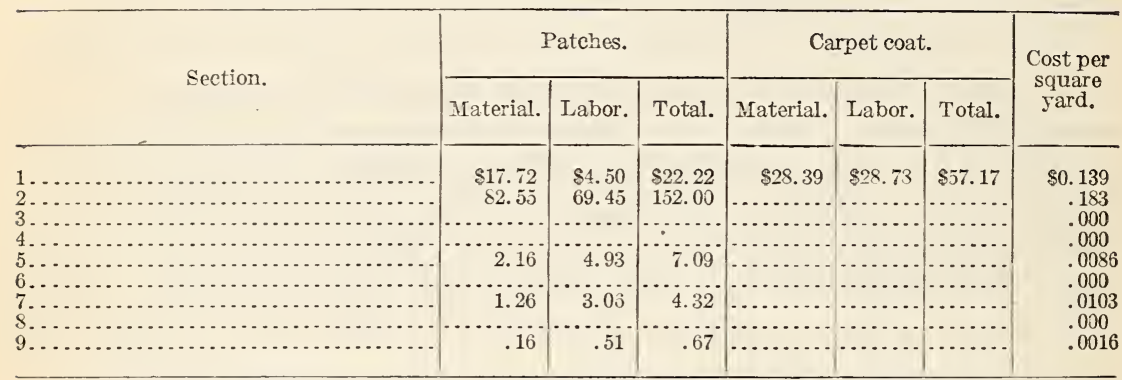

SUPPLEMENTARY REPORT OF EXPERIMENTS MADE AT NEW YORK, N. Y., AND RIDGEWOOD, N. J., 1910 .

\section{OIL-CEMENT CONCRETE.}

The original report of these experiments was published in Circular No. 94, and the reports of annual inspections appeared in Circulars Nos. 98 and 99 . The following report covers inspections made December 17 and 18, respectively.

\section{Experiments at New York, N. Y.}

The general condition of the surface of the road shows gradual deterioration. The edges of the various cracks previously noted have widened and a few minor ones have formed. A new cut has been made in the center of the street from station $3+74$ to station $3+82$, and another from station $3+92$ to station $4+35$. The greatest wear has taken place between station 0 and station $0+15$, where a series of potholes has formed. Otherwise the wear has been uniform.

\section{Experiments at Ridgewood, N. J.}

The floor of the bridge over Saddle River has been covered with a bituminous surfacing and has therefore not been subjected to wear during the past year. The floor of the bridge over Hohokus River was in good condition and no appreciable wear has taken place since the last inspection. 


\section{SUPPLEMENTARY REPORT OF EXPERIMENT MADE AT BOISE, IDAHO, 1910.}

\section{OIL-GRAVEL MACADAM.}

The original report of this experiment was published in Circular No. 94 and reports of annual inspections were given in Circulars Nos. 98 and 99 . The following report covers an inspection made on April 25, 1914:

The south or wide section of the road, which is the portion described in Circular No. 94, was practically all in the same condition and contained a number of potholes. There was, however, no indication of surface disintegration at any point throughout the entire construction. The narrower portion contained a few ruts, but generally speaking it was in fairly good condition. A new flush coat of bituminous material would undoubtedly prove beneficial on some stretches. From the cemetery eastward for a distance of about 1,900 feet the road had just been given a flush coat of a fairly heary asphaltic petroleum product and had been covered with good coarse sand and fine gravel. Such ruts and depressions as had developed from time to time are in all probability due to the poor foundation, which was noted in the original description of the experiment.

SUPPLEMENTARY REPORT OF EXPERIMENT MADE AT AMES, IOWA, 1910.

OIL-ASPHALT GRAVEL.

The original report of this experiment was published in Circular No. 94, and reports of annual inspections were given in Circulars Nos. 98 and 99 . The following report covers an inspection made on January 7, 1914:

The general condition of the section is good, although it was covered with a layer of dust from one-fourth inch to three-fourths inch in thickness. The shape is well preserved, excepting for two or three depressions, and the wear has not been excessive. The surface in general resembled a brown layer of packed gravel and old bituminous material which is "short" and friable.

SUPPLEMENTARY BEPORT OF EXPERIMENTS MADE AT KNOXVILL, TENN., 1910.

TAR AND OIL PREPARATIONS.

The original report of these experiments was published in Circular No.94, and reports of annual inspections are given in Circulars Nos. 98 and 99. 'The following report is based upon an inspection made on December 17, 1913, during a period of cold, damp weather: 
Section No. 1.-Puefined coal tar-Penetration method.

The section was not resurfaced since last inspected, and the surface while not generally loose presented the appearance of a plain macadam road which had been bonded largely by traffic. All of the seal coat, with the exception of two small areas totaling approximately 24 square feet, has been worn off.

Section No. 2.-Refined tar preparation-Penetration method.

Approximately one-half of the seal coat has been worn off and this section showed a rather uneven surface. A number of small raveled places are in evidence, extending generally from the outside of the main traveled way to the edges. The surface of this section has been broken for numerous water connections and the stone replaced in a loose manner without even tamping, and this is thought to be largely responsible for the general appearance of the surface.

\section{Section No. 3.-Oil asphatt-Penetration Method.}

With the exception of the two small depressions noted in the inspection of Norember 22, 1911, this section presented a smooth, well-bonded surface, slightly mosaic in appearance. It could not be dug into with a knife and gave a hard metallic ring under horses' hoois. The depressions were evidently due to settlement, and no raveling has taken place.

\section{SUPPLEMENTARY REPORT OF EXPERIMENTS MADE AT YOUNGSTOWN, OHIO, 1909.}

SLAG, SLAG AND LIME, SLAG AND WASTE SULPHIT LIQUOR PREPARATION, AND SLAG AND TAR.

The original report of these experiments was published in Circular No. 92, and reports of annual inspections are given in Circulars Nos. 94, 98, and 99. The inspection on which the following report is based was made on September 1, 1913, and the sections are discussed in the order of their section numbers, beginning at Mahoning Avenue.

Section No. 1.-Blast-furnace slag; Section No. 2.-Blast-furnace slag and Lime; Section No. 3.-Blast-Furnace slag and Waste sulphite Liquor PrepaRATION.

The wear on these three sections has been quite uniform. The surfaces are well bonded and firm, and the crown is practically the same as when the road was originally constructed. The only difference noted in any of these sections was that on sections Nos. 2 and 3 the No. 1 stone was more in evidence on the surface than in section No. 1, and there were also very slight ruts in the traveled way. 
Section No. 4.-Blast-FurNace slag and Refined COKE-oven tar.

The surface of this section is distinctly mosaic and it is rather rough and uneven, particularly over the fill at the south end of the section. The surface is, as a whole, firm, and about 80 per cent of it is well bonded with tar which still shows considerable life. The section has worn much less than those adjoining it and is now from $1 \frac{1}{2}$ to 2 inches above them.

\section{Sections Nos. 5 and 6.-Blast-Furnace slag.}

In general the surfaces of these two sections are about the same. They are slightly dusty, with the No. 1 stone showing frequently, and there were shallow ruts in the traveled way. In section No. 6 some very large pieces of slag, apparently from 4 to 5 inches in diameter, projected slightly above the surface and there were five shallow worn places on the east quarter.

Section No. 7.-Blast-furnace slag and open-hearth slag.

This section presented the same general surface as sections Nos. 5 and 6. About 100 feet from the south end of the section the road has sunk from 3 to 4 inches over a tile cross drain.

\section{SUPPLEMENTARY REPORT OF EXPERIMENTS MADE AT NEWTON, MASS.,} 1908.

asphaltic preparations, tar preparations, residual oil, and molasses-oilLIME.

The original report of these experiments was published in Circular No. 90, and reports of annual inspections were given in Circulars Nos. 92, 94, 98, and 99. No repairs have been made during the past year and the following report covers an inspection made on December 13, 1913.

Experiments Nos. 1, 2, 3, 4, 5, 6, and 7.-Asphaltic preparation-Mixing METHOD.

The surfacing of experiments Nos. 1 to 4, inclusive, was gradually disappearing, and the west half of experiment No. 5 had deteriorated seriously during the past year. There had been little change in the condition of experiments Nos. 6 and 7, excepting for the fact that the holes reported at the last inspection had slightly increased in area during the year. In experiment No. 7 two additional holes, each about 1 square foot in area, had developed. These are in the wheel tracks and will continue to enlarge.

Experiment No. 8.-Residual Petroleum-Mixing Method.

This section had not changed appreciably since it was inspected a year ago, excepting for the fact that eight small pits were developing. 
A surface treatment of the entire section is recommended to prerent further disintegration.

Expernits Nos. 9 AND 10.-Refined WAter-Gas TAR-Mining Method.

These sections were in excellent condition. The west end of section No. 10 had been treated with an asphaltic oil for a distance of about 35 feet where the street beyond the experiment was repaired.

\section{SUPPLEMENTARY REPORT OF EXPERMENTS MADE AT GARDEN CITY, DODGE CITY, BUCKLIN, AND FORD, KANS., 1908.}

SAND CLAY.

The original report of these experiments was published in Circular No. 90, and reports of annual inspections are giren in Circulars Nos. 92, 94, 98, and 99. The following are reports of inspections made in 1913.

\section{Experiment at Garden City.}

The Santa Fe Road at Garden City, Kans., 12 by 765 feet, was inspected on December 19, and found to be in poor condition. The recent rains hare had a damaging effect upon the gypsum clay surfacing, and hare softened it into a muck-like condition varying from 2 to 4 inches in depth. This is more noticeable at the north end where some new gypsum has been added without sand, but the mud is in evidence throughout the entire course. The road has recently been worked with a small 2-horse grader, and the material has been pushed to the center in such a way as to give a uniform slope and crown. The road is reported to hare been in excellent condition all last summer and will be so again as soon as it is dried out.

\section{Expernett at Dodge City.}

The Ifineola Road, improred by a clay and sand composition 14 by 9,750 feet, was inspected on December 19, 1913, and found to be generally in good condition throughout the whole course, with one exception, where a chuck hole of minor importance was in eridence. The ditches were in good order, the cross section uniform, and the edges of surfacing not broken by the attacks of traffic. It has been well maintained by dragging done by a near-by farmer whenerer necessary, but, owing to recent and continuous rains for two weeks, the surface of the roadway had softened to the extent of being deformed by traffic, showing slight hoof marks and incipient ruts. At the extreme north end, for a distance of 75 feet, some new material has been added and left in an unfinished condition.

\section{Experment at Beckin.}

The Spearrille Road, at Bucklin, Kans., was inspected on December 20, 1913, and the clared surfacing, which was 14 by 4,271 feet, 
was found to be in fairly good condition. The part at the north end, and especially the high part that forms the approach to the bridge over the Arkansas River, was smooth and free from ruts, owing to more rapid drainage. The balance of the course was rutted to some extent, because of an unusual amount of rain and trafiic, and had frozen solid the night before inspection. The width, grade, cross section, and slope were uniform. No new material has been added this year and proper attention to maintenance has been accomplished by dragging.

\section{Experiment at Ford.}

The Spearville Road at Ford, Kans., was inspected on December 20, and found to be in good condition with the exceptions noted. The 16-foot width of surfacing was uniform as to slope, grade, and crown throughout the entire length of 350 feet, and showed no evidence of failure to carry the traffic, except slight ruts and hoof marks, which were due to the fact that recent rains had softened the surface of the roadway to a depth of about 1 inch. The road is high and well drained in every way, and gave evidence of "standing up" very well under climatic conditions and traffic. It has been maintained at a very low cost by the use of the split-log drag.

\section{SUPPLEMENTARY REPORT OF EXPERIMENT MADE AT INDEPENDENCE, KANS., 1908.}

OIL-ASPHALT EARTH ROAD.

The original report of this experiment was published in Circular No. 90, and reports of annual inspections are given in Circulars Nos. 92, 94, 98, and 99. The following report is based upon an inspection. made December 22, 1913.

The inspection was made under unfavorable conditions, as the ground was covered with snow from 2 to 3 inches deep and conclusions are largely based on information received in the light of reports. The part known as Tonopah Drive is now really an earth road, and was worked into condition about two months ago. It carries a mixed traffic with a maximum load of 6,000 pounds, and has developed ruts along the center, while the sides are fairly smooth. The ditches are well cleaned out and in good order, and the road has a good crown and uniform cross section. The part known as Minnehaha Street was also worked over along with Tonopah Drive and is in good condition with the exception of incipient ruts. The foundation, material, and drainage are much better than on Tonopah Drive and show very few signs of failure from climatic conditions or traffic. No attempt has been made to add more asphalt binder and to bring the road into its original condition as first constructed. 


\section{SUPPLEMENTARY REPORT OF AN EXPERIMENT MADE AT BOWLING GREEN, KY., 1907.}

\section{KENTUCKY ROCK ASPHALT.}

The original report of this experiment was published in Circular No. 89 and reports of annual inspections are given in Circulars Nos. $90,92,94,98$, and 99 . The inspection. on which the following report is based was made on January 5, 1914:

For a distance of 50 feet from the west end of the section the north half of the road is badly worn and more than 50 per cent of the asphaltic surface is gone. The south half of the road is in fair condition.

In the remaining length of the section there are 33 depressions from 1 to 3 feet in diameter and from 1 to 3 inches in depth, which indicate partial or complete failure of the asphaltic surface. However, as a whole, this portion of the road is in a very fair condition, but it would appear that unless the surface is soon repaired the entire experiment will materially fail within the next year. Disintegration has been quite rapid since a mid-year inspection made on July 8, 1913.
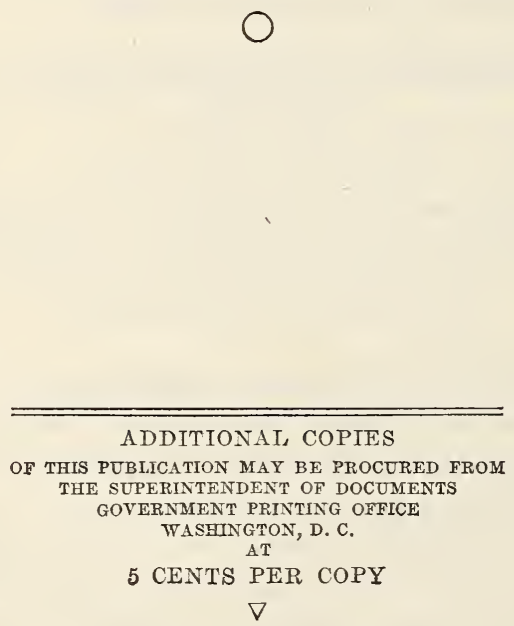